\title{
Hydrography and currents on the Pernambuco Continental Shelf
}

\author{
Hidrografia e correntes da Plataforma Continental de Pernambuco
}

\author{
Ernesto de Carvalho Domingues ${ }^{1}$, Carlos Augusto França Schettini ${ }^{2}$, Eliane Cristina Truccolo ${ }^{2}$ and José Cavalcante de Oliveira Filho ${ }^{2}$ \\ ${ }^{1}$ Universidade Federal de Sergipe, Aracaju, SE, Brazil \\ ${ }^{2}$ Universidade Federal de Pernambuco, Recife, PE, Brazil \\ E-mails: ernestocd@yahoo.com.br (ECD),gutoschettini@gmail.com (CAFS), nane.truccolo@gmail.com (ECT), josefilho77@gmail.com (JCF)
}

Received: February 14, 2017 - Revised: April 19, 2017 - Accepted: May 15, 2017

\begin{abstract}
The present study presents the seasonal hydrography and currents of the Brazilian Northeast Continental Shelf. The study area is located on the Brazilian tropical coast of the Atlantic Ocean between 7.5 and $9{ }^{\circ} \mathrm{S}$. This continental shelf is narrow ( $\sim 35 \mathrm{~km}$ wide) and shallow, with shelf break lying at a depth of $60 \mathrm{~m}$. Salinity and temperature data were collected monthly by means of hydrographic surveys, conducted across the shelf in a single transect in the central part of the study area, between March 2012 and May 2013 . Two further campaigns were also conducted to characterize the winter (August 2013) and the summer (January 2014), covering the whole study area $\left(4,600 \mathrm{~km}^{2}\right)$. Water level and currents were measured using an array of Acoustic Doppler Current Profilers (ADCP) moored at mid-shelf in the central area. Seasonal temperature ranged from $26{ }^{\circ} \mathrm{C}$ in September to $29.5^{\circ} \mathrm{C}$ in April, with a 2 -month lag between the minimum and maximum air temperatures. Salinity did not present a clear seasonal pattern, fluctuating between 36.5 and 37.0 psu throughout the year. The mean temperature and salinity values obtained in the winter and summer campaigns were 26.5 and $27.6{ }^{\circ} \mathrm{C}$ and 37.1 and 36.7 psu, respectively. Tropical Water (TW) was predominant, accounting for 95\% to $97 \%$, with presence of Coastal Water $(\mathrm{CW})$ limited to the inner part of the shelf. The mean flow velocity values in the water column in winter and summer were 0.11 and $0.06 \mathrm{~m} / \mathrm{s}$, respectively, similarly to the seasonal wind regime. Northward currents were observed predominantly in winter, with a short period of inverted southward current. These episodes were related to periods of wind relaxation and presented periodicity of 6-13 days, observed through wavelet analysis. This periodicity may be associated with atmospheric instabilities at higher latitudes. Summer currents were sluggish, when the tides accounted for 75 and $43 \%$ of the variance in the cross- and along-shelf current components, respectively. TW is the main water mass in the Pernambuco Continental Shelf (PCS) in summer and winter. Current intensity is weak and without direction in summer and stronger towards the north in winter.
\end{abstract}

Keywords: Water masses; Circulation; Brazilian Northeast Shelf.

\section{RESUMO}

Este trabalho apresenta a descrição sazonal da hidrografia e hidrodinâmica de uma plataforma continental localizada na borda oeste do Atlântico tropical, a área de estudo encontra-se entre as latitudes de 7,5 e $9{ }^{\circ} \mathrm{S}$, possui apenas $35 \mathrm{~km}$ de largura e $187 \mathrm{~km}$ de extensão, com a quebra de plataforma em $60 \mathrm{~m}$ de profundidade. A salinidade e temperatura foram coletadas em campanhas hidrográficas mensalmente entre março de 2012 e maio 2013 por meio de transectos na região central da área de estudo. Também, duas campanhas foram realizadas, uma para caracterizar o inverno (Agosto de 2013) e outra o verão (janeiro de 2014) cobrindo toda a área de estudo $\left(4600 \mathrm{~km}^{2}\right)$. O nível da água e correntes também foram coletados com um Perfilado Acústico por efeito Doppler (ADCP) fundeado na região central da área de estudo. A variação sazonal de temperatura variou entre $26^{\circ} \mathrm{C} \mathrm{em} \mathrm{setembro} \mathrm{e} 29,5^{\circ} \mathrm{C}$ em abril, com um atraso de dois meses entre a temperatura mínima e máxima do ar atmosférico. A salinidade não apresentou variabilidade sazonal, estando entre 36,5 e 37,0 psu. A média de temperatura e salinidade das campanhas no inverno e no verão foram de 26,5 e $27,6^{\circ} \mathrm{C}$ e 37,1 e 36,7 psu, respectivamente. A Água tropical (AT) foi dominante, contabilizando 95\% a 97\%, com a presença de Águas Costeiras (AC) limitadas na região próximo da costa. A médias de velocidade de corrente na coluna d'água no inverno e no verão foi de 0,11 e $0.06 \mathrm{~m} / \mathrm{s}$, refletindo o regime sazonal dos ventos. As correntes no inverno foram predominantes na direção norte, com um pequeno período de inversão para direção sul. Estes episódios ocorreram quando houve o relaxamento do vento e com a periodicidade entre 6-13 dias, retratado 
com a análise de ondeletas. Esta periodicidade pode estar associada com a instabilidade atmosférica em latitudes mais elevadas. As correntes no verão foram fracas, quando as marés contabilizaram $75 \%$ e $43 \%$ da variância nas correntes transversais e longitudinal respectivamente. A AT é a massa de água predominante na plataforma continental pernambucana no verão e no inverno, a intensidade das correntes no verão é fraca e sem direção definida e no inverno são mais fortes com o sentido norte.

Palavras-chave: Circulação costeira; Massas de água; Variação termohalina.

\section{INTRODUCTION}

Continental shelves are underwater regions which extend from a coastline to a continental slope. They commonly occur along passive continental margins, comprising $7.5 \%$ of the total area of the oceans (SCHMIEGELOW, 2004). They generally present smooth gradient (e.g., 1:1000), width ranging from tens to hundreds of kilometers, and are much shallower compared to the adjacent ocean. The continental shelf is the region where interactions between the estuary and the ocean occur. It is usually divided into three parts: inner-, middle-, and outer-shelf, showing shallower conditions in the first portion and oceanic conditions in the latter part (WRIGHT, 1995). The dynamics in this environment is controlled by tides, wind regime, baroclinic effects, and interactions with mesoscale ocean circulation (KNOPPERS; EKAU; FIGUEIREDO, 1999).

The hydrographic characteristics, represented by areas of salinity and temperature distribution, are quite variable and depend on latitude, geology, interaction with the atmosphere, and proximity of discharge of large rivers. Temperature is mainly influenced by local radiative balance (latitude) and interaction with the adjacent ocean (e.g., resurgence). Salinity is mostly influenced by the interaction with the adjacent ocean, but contribution from the continent plays an important role in the inner portion of the shelf. In the case of shelf areas by the mouth of large rivers, such as the River Plate, salinity is directly associated with the fluvial regime (ORTEGA; MARTÍNEZ, 2007).

The Brazilian continental shelf ranges in width from a few kilometers along the coast of Bahia state $(\sim 8 \mathrm{~km})$ to hundreds of kilometers off the coast of Para state $(\sim 300 \mathrm{~km})$ (SCHMIEGELOW, 2004); as for shelf break, it varies in depth between 60 (MANSO; CORREA; GUERRA, 2003) and $180 \mathrm{~m}$ (CASTRO, 1990). In general, the Brazilian Northeast Continental Shelf presents average width of approximately $40 \mathrm{~km}$ and shelf break lyimg at depths between 50 and $60 \mathrm{~m}$ (VITAL et al., 2010). Temperature $\left(27^{\circ} \mathrm{C}\right)$ and salinity $(>36)$ are high in most of the shelf, except in its the inner portion and in the vicinity of the mouth of the Sao Francisco (Sergipe and Alagoas states) and Parnaiba (Piaui state) Rivers. Considering that the shelf under study is relatively narrow and receives reduced fluvial contribution, its hydrographic characteristics are potentially influenced by surface mesoscale ocean currents. Figure 1 shows a scheme of the currents in the western edge of the tropical Atlantic Ocean. Between latitudes 11 and $15^{\circ} \mathrm{S}$, the South Equatorial Current (SEC) bifurcates (STRAMMA; PETERSON, 1990) to form the Brazil Current (BC) to the south and the North Brazil Undercurrent (NBUC) to the north (SCHOTT et al., 2005). Thus it is expected that

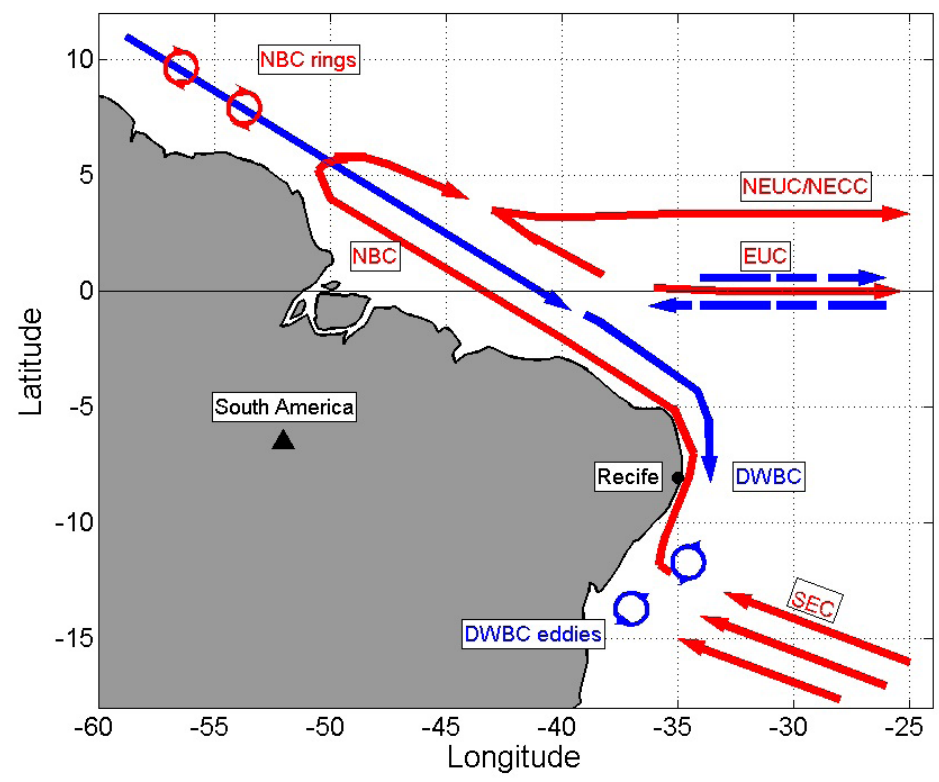

Figure 1. Circulation in the western edge of the tropical Atlantic Ocean (modified by Dengler et al., 2004). The red lines represent surface currents, whereas the blue lines depict undercurrents. Current branches indicated are the South Equatorial Current (SEC), the North Brazil Undercurrent (NBUC), the North Brazil Current (NBC), the Equatorial Undercurrent (EUC), the North Equatorial Countercurrent (NECC), and the Deep Western Boundary Current (DWBC). 
the hydrographic characteristics of the continental shelf under study be directly related to Tropical Water (TW) advected by the SEC and the NBUC. The Deep Western Boundary Current (DWBC) occurs at greater depth, although without direct influence on the continental shelf of the west tropical Atlantic Ocean (DENGLER et al., 2004).

Some studies analyzing the Brazilian continental shelf have been conducted mainly on its southeast and south regions (EMÍLSSON, 1961; MIRANDA, 1985; CARVALHO; SCHETTINI; RIBAS, 1998; PEREIRA et al., 2007; MOLLER JUNIOR et al., 2008; HILLE; SCHETTINI; RIBEIRO, 2008, among others). Nevertheless, research on the northeast and north regions are scarcer, e.g., Geyer et al. (1996) in the area off the mouth of the Amazon River (Para and Amazonas states) and Dias, Castro and Lacerda (2013) in the region of the mouth of the Jagaribe River (Ceara state).
In this context, the purpose of this study is to present a descriptive hydrographic analysis of a continental shelf located on the western edge of the tropical Atlantic Ocean, considering that this part represents typical conditions for the shelf area north of the bifurcation of the SEC. The data analyzed include across- and along-shelf distribution of salinity and temperature on the entire shelf, as well as time series of velocity and direction of currents obtained at two modal wind conditions (January and August) and in monthly surveys conducted in the central portion of the Pernambuco Continental Shelf (PCS).

\section{Study area}

The PCS is $187 \mathrm{~km}$ long and $35 \mathrm{~km}$ wide, with shelf break between 50-60 $\mathrm{m}$ deep (Figure 2). The shelf bed is composed of tergenic sediments and biogenic carbonates. A feature of

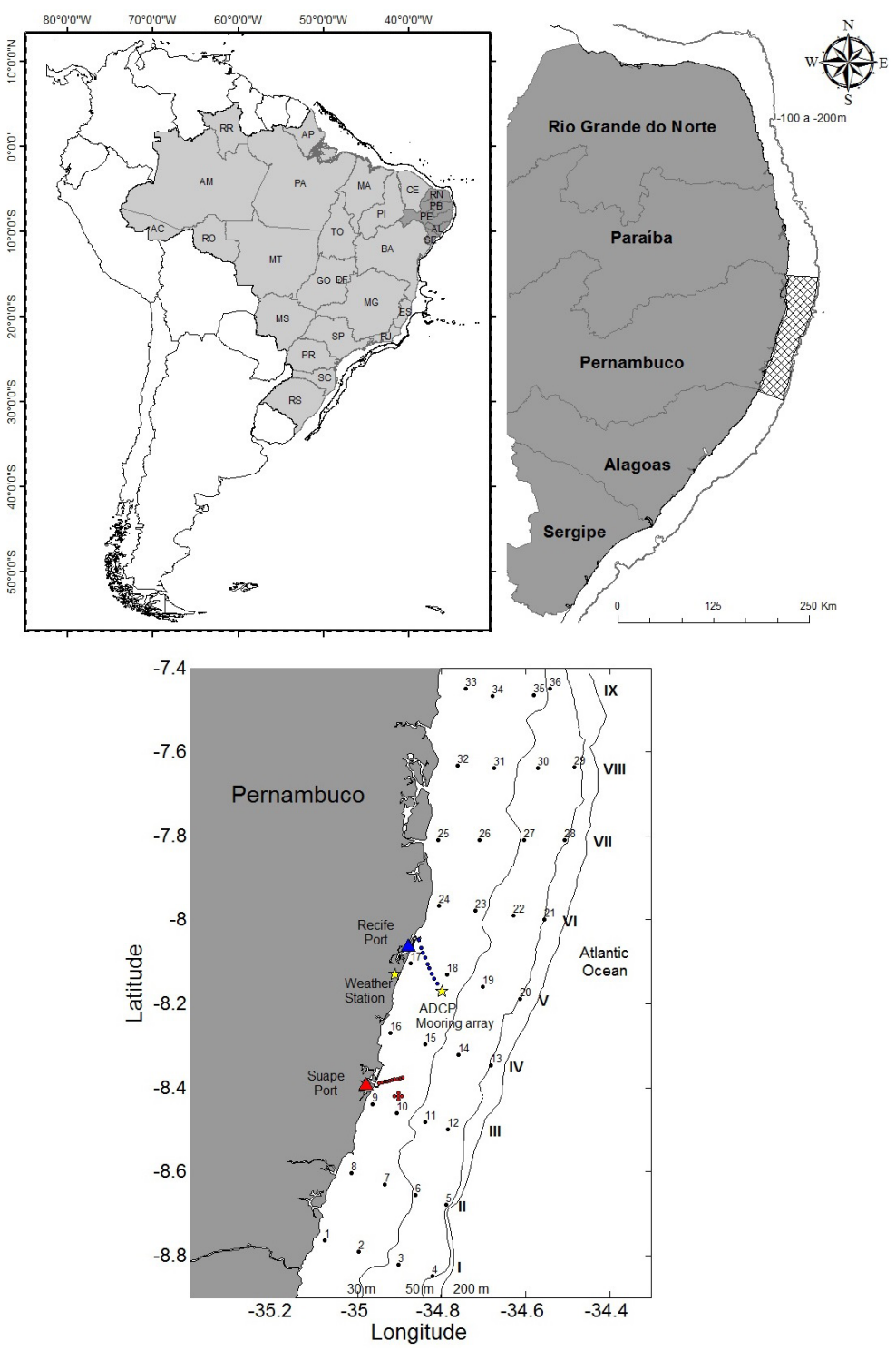

Figure 2. Location of the study area. Numbered black dots indicate stations commissioned during the campaigns of August 2013 and January 2014. Blue dots represent the stations of the monthly surveys. The yellow stars indicate the locations of the weather station and of the ADCP mooring array. 
this region is the presence of a line parallel to the coast formed by submerged and semi-submerged calcareous rocks lying along nearly all the shelf length (MANSO; CORREA; GUERRA, 2003).

Climate in the region is semi-arid, although the coastal strip presents humid tropical climatic conditions. The average annual temperature in Recife is $25.8^{\circ} \mathrm{C}$, with monthly mean values ranging between 24.1 and $26.9^{\circ} \mathrm{C}$ in July and January, respectively (Table 1; Figure $3 \mathrm{~A}$ ). Wave climate in the region presents minimum and maximum significant heights of $0.97 \mathrm{~m}$ and $3.37 \mathrm{~m}$, with mean of $1.5 \mathrm{~m}$; the peak period is 8 to $10 \mathrm{~s}$ and the incidence direction is between $\operatorname{ESE}\left(105^{\circ}\right)$ and $\mathrm{S}\left(182^{\circ}\right)$, with mean direction towards SE $\left(139^{\circ}\right)$ (PEREIRA; NOGUEIRA NETO, 2010). Rainfall on the coast is approximately $2,400 \mathrm{~mm}$ /year (RAMOS; SANTOS; FORTES, 2009), and it is influenced by the local orography by the Serra da Borborema (PEREIRA, 2013). Rainfall distribution presents strong seasonal modulation, with maximum precipitation between June and July (Table 1; Figure 3B). The pluviometric regime varies significantly throughout the year owing to the El Niño-Southern Oscillation (ENSO) (ANDREOLI; KAYANO, 2007).

The local wind regime is controlled by the semi-permanent, high-pressure system of the South Atlantic Ocean. Analysis of the wind data recorded between 2000 and 2007 at Ipojuca weather station (-8.51 S and -35.00 W; National Environmental Data System (SINDA) of the National Institute for Space Research (INPE)) shows that the mean monthly wind velocity varies from $7.5 \mathrm{~m} / \mathrm{s}$ in summer (December and January) to almost $10 \mathrm{~m} / \mathrm{s}$ in winter (August and September), with predominant east direction in summer and southeast in winter (Table 1; Figure 3C).

Direct fluvial contribution to the PCS originates from a series of small coastal rivers that totalize drainage of an area of $26,800 \mathrm{~km}^{2}$ (BRASIL, 2006). The main rivers that flow into the continental shelf of Pernambuco are Goiana, Capibaribe, Ipojuca, Sirinhaem, and Una. The discharge of these rivers is determined not only by the regime of coastal rain (Zona da Mata), but also by the semi-arid climate in the Zona do Agreste, where rainfall is considerably lower, which results in relatively low discharges (SCHETTINI et al., 2016b). The integrated annual mean flow is of approximately $120 \mathrm{~m}^{3} / \mathrm{s}$, with yearly variation responding directly to the pluviometric regime (Table 1; Figure 3D). Among these rivers, the Capibaribe River is particularly relevant, considering that its estuary crosses the metropolitan region of Recife - a potential source of pollutants for the adjacent shelf (SCHETTINI et al., 2016a; MACIEL et al., 2016).

Regional tides are semidiurnal with a form factor of 0.09 . The tidal form factor $(\mathrm{F})$ is obtained by the ratio between the sum of the amplitudes of the main diurnal harmonic constituents and the sum of the amplitudes of the main semidiurnal harmonic constituents (PUGH, 1987), calculated as $\mathrm{F}=\left(\mathrm{O}_{1}+\mathrm{K}_{1}\right) /\left(\mathrm{M}_{2}+\mathrm{S}_{2}\right)=0.09$. Harmonic tidal constituents for the coast of Pernambuco state are available at FEMAR (2000). Tide height can vary between 0.7 and $2.5 \mathrm{~m}$ under quadrature and syzygy conditions, respectively. The astronomical signal contributes $99.7 \%$ of the water level variance (FROTA; TRUCCOLO; SCHETTINI, 2016).

Information on the thermohaline characteristics and circulation for the PCS is scarce. A study conducted in 2005 using drift cards showed that the currents on this shelf are preferentially northward during winter (June) and southward during summer (February) (LIRA et al., 2010). Although most recoveries of the launched cards (5,000 at each launching) were reported within a dozen kilometers from the launching, the furthest records were in Maranhao state to the north $(\sim 1300 \mathrm{~km})$ and in Bahia state to the south $(\sim 1000 \mathrm{~km})$. Data obtained from a half-water mooring on the Rio Grande do Norte shelf (-5.04 S and $-35.20 \mathrm{~W})$, at a depth of $35 \mathrm{~m}$, between December 2001 and July 2002, indicated that currents to the northeast transect accounted for $52.2 \%$, whereas currents to southeast transect accounted for $32.5 \%$ of the observations, with intensity raging between 0.05 and $0.10 \mathrm{~m} / \mathrm{s}$ (HAZIN et al., 2008). The temperature during this period ranged from $25.8{ }^{\circ} \mathrm{C}$ (July) to $28.7^{\circ} \mathrm{C}$ (February).

The oceanic region off the shelf under study is controlled by the North Brazil Undercurrent (NBUC), originated from the bifurcation of the SEC at about $10.5^{\circ} \mathrm{S}$, and with transport to the north of approximately $21 \mathrm{~Sv}$, presenting high salinity values ( 37) (SILVEIRA; MIRANDA; BROWN, 1994; MARIN, 2009). Surface temperature is approximately $28{ }^{\circ} \mathrm{C}$, with permanent thermocline as of $100 \mathrm{~m}$ (SCHOTT et al., 2005; SILVA et al., 2009). These values of salinity and temperature are characteristic of Tropical Water.

Table 1. Climatic values of air temperature and rainfall for Recife (RAMOS; SANTOS; FORTES, 2009), wind velocity and direction for Ipojuca, sum of fluvial discharges from the main rivers that flow onto the coast of Pernambuco state, and their annual mean values.

\begin{tabular}{|c|c|c|c|c|c|}
\hline & \multirow{2}{*}{$\frac{\text { Temperature }}{\left(^{\circ} \mathrm{C}\right)}$} & \multirow{2}{*}{$\frac{\text { Rainfall }}{(\mathrm{mm})}$} & \multicolumn{2}{|c|}{ Wind } & \multirow{2}{*}{$\frac{\text { Discharge }}{\left(\mathrm{m}^{3} / \mathrm{s}\right)}$} \\
\hline & & & Velocity $(\mathrm{m} / \mathrm{s})$ & Direction (degree) & \\
\hline January & 26.9 & 103.4 & 7.5 & 96 & 52.0 \\
\hline February & 26.9 & 144.2 & 8.4 & 112 & 74.5 \\
\hline March & 26.8 & 264.9 & 8 & 124 & 65.5 \\
\hline April & 26.1 & 326.4 & 7.6 & 139 & 94.3 \\
\hline May & 25.6 & 328.9 & 7.8 & 145 & 147.6 \\
\hline June & 24.7 & 389.6 & 8.6 & 156 & 245.4 \\
\hline July & 24.1 & 385.6 & 8.8 & 158 & 253.5 \\
\hline August & 24.4 & 213.5 & 9.6 & 147 & 177.1 \\
\hline September & 25.2 & 122.5 & 9.7 & 132 & 118.2 \\
\hline October & 26.0 & 66.1 & 9.2 & 110 & 74.7 \\
\hline November & 26.4 & 47.8 & 9.8 & 90 & 52.0 \\
\hline December & 26.4 & 65.0 & 9.7 & 91 & 44.4 \\
\hline Mean & 25.8 & 204.8 & 8.7 & 124.9 & 116.6 \\
\hline
\end{tabular}


(A)

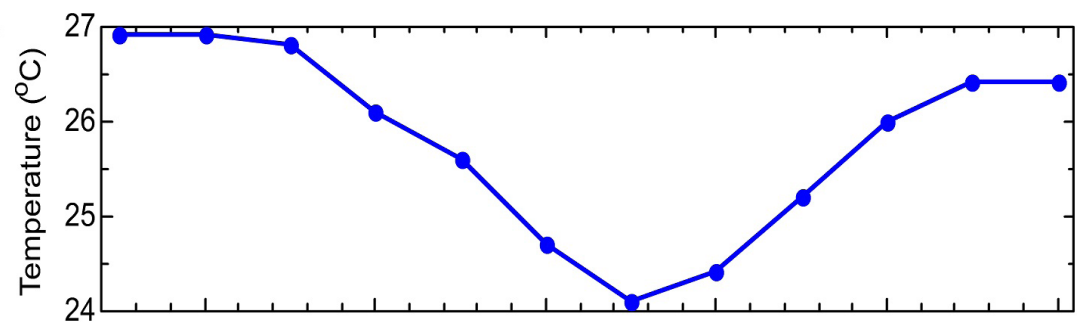

(B)

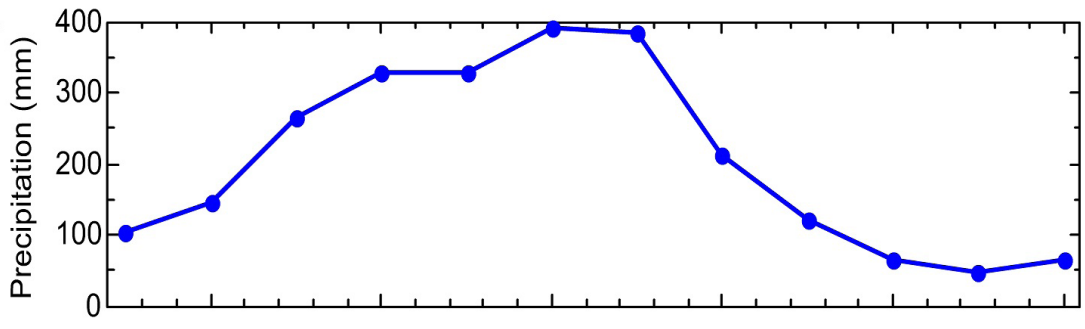

(C) Wind vectors

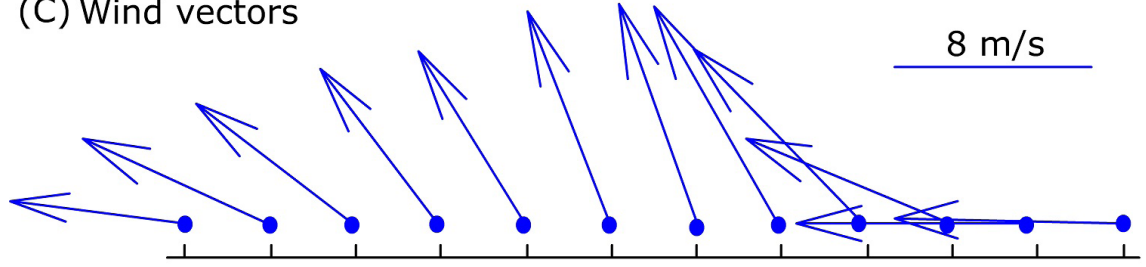

(D)

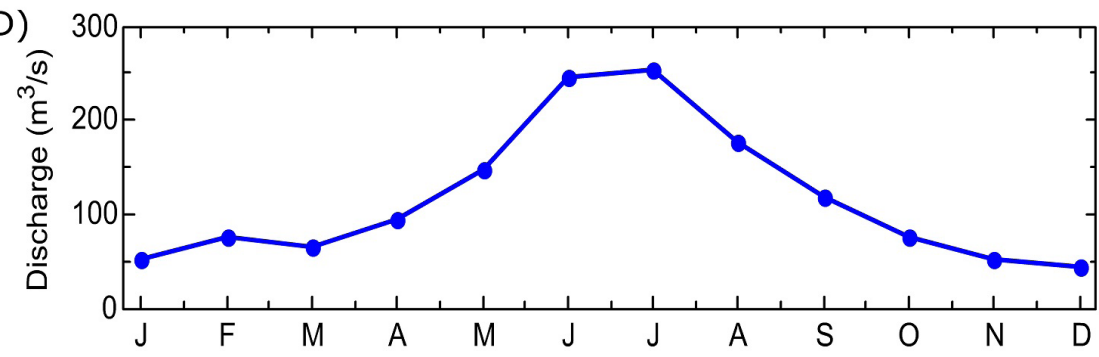

Figure 3. Annual variation of (A) temperature and (B) rainfall in Recife, (C) wind vectors in Ipojuca, and (D) sum of fluvial discharge on the coast of Pernambuco state.

\section{MATERIALS AND METHODS}

The data of salinity and temperature used in this work were obtained from monthly conducted opportunity surveys and in two oceanographic campaigns specific for this study (Table 2). The opportunity campaigns were conducted taking advantage of the routine displacement of vessels on routes approximately perpendicular to the coastline in two locations: one off the coast of Recife and one off the coast of Suape, distant approximately $30 \mathrm{~km}$ from each other (blue and red dots in Figure 2). The navigation off Recife aimed at maintenance activities in aquaculture sites, whereas navigation off Suape aimed at environmental monitoring activities of the harbor dredging. A total of 17 surveys were conducted: seven in the first case and 10 in the latter case. In both cases, data of temperature and salinity were recorded at intervals of $1 \mathrm{~km}$ from the coast up to approximately $25 \mathrm{~m}$ depth and distance of about $12 \mathrm{~km}$ offshore. The surveys were conducted in different months of the year, thus allowing time assessment of thermohaline variability of the inner shelf. A Cond Tem Depth (CTD) Rinko-Profiler model instrument, JFE-Advantech manufactured, was used in all campaigns with acquisition rate of $10 \mathrm{~Hz}$, temperature resolution of $0.001{ }^{\circ} \mathrm{C}$, and conductivity resolution of $0.001 \mathrm{mS} / \mathrm{cm}$. Salinity values were converted using the Practical Salinity Scale - PSS-78 (UNESCO, 1981).

The oceanographic campaigns were conducted under winter (August 2013) and summer (January 2014) modal conditions. Alongshore CTD profiles were performed at 36 stations distributed in 9 transects (I to IX) approximately perpendicular to the coastline, each transect with 4 stations between a depth of $7 \mathrm{~m}$ and the shelf break $(\sim 60 \mathrm{~m})$. These campaigns were conducted mainly on the coast of Pernambuco state, covering an extension of $160 \mathrm{~km}$ and mean width of $40 \mathrm{~km}\left(\sim 6,400 \mathrm{~km}^{2}\right)$. The data of salinity and temperature were described in terms of their seasonal mean variation, the winter and summer temperature-salinity (TS) diagrams, and from the spatial distributions of surface and bottom, and in cross sections.

During the oceanographic campaigns, data for water level and current velocity and direction were recorded using an Acoustic Doppler Current Profiler (ADCP) moored off the coast of Recife (-8.15 S; -34.85 W, Figure 2). An ADCP, Sontek manufactured, Argonaut XR model, of $750 \mathrm{kHz}$ was used in the August 2013 campaign, whereas an ADCP, Nortek manufactured, 
Table 2. List of conducted data collection campaigns indicating date, number of stations commissioned (NS), and the minimum, mean, maximum and standard deviation values.

\begin{tabular}{rccccccccccc}
\hline$\#$ & Campaign & yy-mm-dd & $\mathbf{N S}$ & $\mathbf{T}_{\text {MIN }}$ & $\mathbf{T}_{\text {AVG }}$ & $\mathbf{T}_{\text {MAX }}$ & $\mathbf{T}_{\text {STD }}$ & $\mathbf{S}_{\text {MIN }}$ & $\mathbf{S}_{\text {AVG }}$ & $\mathbf{S}_{\text {MAX }}$ & $\mathbf{S}_{\text {STD }}$ \\
\hline 1 & Recife & $12-03-08$ & 10 & 28.5 & 28.6 & 28.6 & $>0.1$ & 31.1 & 36.9 & 37.1 & 0.4 \\
2 & Recife & $12-04-13$ & 10 & 28.4 & 28.6 & 28.7 & $>0.1$ & 35.3 & 37.3 & 37.4 & 0.2 \\
3 & Recife & $12-05-11$ & 10 & 27.8 & 28.3 & 28.3 & $>0.1$ & 36.1 & 37.4 & 37.6 & 0.1 \\
4 & Recife & $12-07-20$ & 7 & 26.4 & 26.7 & 26.8 & 0.1 & 36.4 & 36.6 & 37.0 & 0.2 \\
5 & Recife & $12-09-06$ & 17 & 25.8 & 26.0 & 26.3 & 0.1 & 30.9 & 37.0 & 37.7 & 0.5 \\
6 & Recife & $12-10-11$ & 19 & 26.0 & 26.3 & 26.5 & 0.1 & 29.9 & 36.6 & 37.2 & 0.7 \\
7 & Recife & $12-11-24$ & 19 & 26.1 & 27.0 & 28.0 & 0.5 & 35.4 & 37.0 & 37.6 & 0.3 \\
8 & Suape & $12-11-30$ & 28 & 26.5 & 27.4 & 28.3 & 0.4 & 33.9 & 36.7 & 37.0 & 0.3 \\
9 & Suape & $12-12-14$ & 26 & 25.5 & 27.3 & 28.6 & 0.7 & 36.8 & 37.0 & 37.3 & 0.1 \\
10 & Suape & $12-12-20$ & 26 & 25.9 & 26.9 & 28.7 & 0.9 & 36.5 & 37.0 & 37.2 & 0.1 \\
11 & Suape & $13-01-10$ & 28 & 27.7 & 28.2 & 29.1 & 0.3 & 36.2 & 37.0 & 37.1 & 0.1 \\
12 & Suape & $13-02-22$ & 26 & 28.2 & 28.5 & 29.4 & 0.2 & 34.1 & 37.1 & 37.2 & 0.1 \\
13 & Suape & $13-02-28$ & 26 & 28.5 & 28.8 & 29.9 & 0.2 & 37.0 & 37.2 & 37.5 & $>0.1$ \\
14 & Suape & $13-03-14$ & 20 & 27.6 & 28.9 & 29.6 & 0.4 & 37.0 & 37.2 & 37.9 & 0.1 \\
15 & Suape & $13-04-04$ & 20 & 29.0 & 29.2 & 30.6 & 0.2 & 36.4 & 37.3 & 37.4 & 0.5 \\
16 & Suape & $13-04-13$ & 9 & 28.4 & 28.6 & 28.7 & $>0.1$ & 35.3 & 37.3 & 37.4 & 0.2 \\
17 & Suape & $13-05-20$ & 26 & 27.9 & 28.0 & 28.6 & 0.1 & 34.9 & 36.5 & 36.9 & 0.3 \\
18 & PCS & $13-08-16$ & 35 & 25.2 & 26.5 & 27.3 & 0.4 & 35.2 & 37.1 & 37.4 & 0.2 \\
19 & PCS & $14-01-09$ & 36 & 24.8 & 27.6 & 28.8 & 0.5 & 35.6 & 36.7 & 37.1 & 0.1 \\
\hline
\end{tabular}

$>$ Bigger than

Aquadopp model, of $1000 \mathrm{kHz}$ was utilized in the January 2014 survey. In both cases, the devices were configured to record data at 1-hour intervals, from 3-minute means, at an acquisition rate of $2 \mathrm{~Hz}$. In the winter campaign, data were recorded from August 17 to September 29 (43 days), whereas in the summer campaign, the recording period was from January 10 to 18 (9 days).

Data of the currents were analyzed in terms of the mean velocity of water column, decomposed into the cross-shore $(U)$ and alongshore $(V)$ components ( $\sim 18^{\circ}$ to the north). Each component was additionally decomposed into harmonic and non-harmonic components by means of tidal harmonic analysis (PAWLOWICZ; BEARDSLEY; LENTZ, 2002). Synoptic wind data auxiliary to the recording of currents were obtained for the weather station of Recife airport (-8.13 S; -34.91 W).

Visual inspection revealed a possible association between the records of wind and alongshore non-harmonic current. Based on these data, the power spectra, the energy coherence by wavelet analysis, and the phase spectrum were calculated following the procedures described in Torrence and Compo (1998) and Grinsted, Moore and Jevrejeva (2004); the coherence of energy between them was also analyzed.

\section{RESULTS AND DISCUSSION}

Studies on continental shelves are limited by variables that preclude or hinder the acquisition of data, such as ocean conditions, risk of theft of moored equipment, and availability of vessels suitable for periodic maintenance of the instruments. In order to describe opposing situations, the present study focused on the two situations considered extreme for the region: the month of August, known to present more intense winds, when it was possible to collect data of currents for 45 continuous days; and January, which is the month that represents the classic summer in northeastern Brazil, when it was possible to collect data for 9 days.
Figure 4 shows the mean time variations of temperature and salinity obtained from the opportunity surveys conducted between March 2012 and May 2013. The variation of water temperature presented a behavior that reflects the seasonal variability, but with a 2 -month lag in relation to the values of air temperature. The lowest and highest temperatures were recorded at the beginning of September (2012) and April (2013), with thermal amplitude of $3{ }^{\circ} \mathrm{C}$. It was not possible to identify a seasonal pattern for salinity; however, although these data reflect coastal hydrographic conditions, the lowest mean salinity value was 36.5 psu. The mean values of temperature and salinity for the whole dataset were $27.8 \pm 1.0{ }^{\circ} \mathrm{C}$ and $37.0 \pm 0.3$, respectively, indicating relatively small time variability.

Figure 5 shows the Temperature-Salinity (T-S) diagrams for the data obtained in the winter and summer campaigns. In both situations, there is predominance of Tropical Water (TW), with few occurrences of Coastal Water (CW) $(\mathrm{S}<36.5)$. The mean values and standard deviation for temperature were $26.5 \pm 0.3$ and $27.6 \pm 0.5{ }^{\circ} \mathrm{C}$ in winter and summer, respectively, and salinity values were $37.1 \pm 0.3$ and $36.7 \pm 0.1$ in the same order. In the winter campaign, the thermal variation of TW ranged from 25 to $27^{\circ} \mathrm{C}$, whereas in summer the thermal amplitude was between 24.8 and $28.7{ }^{\circ} \mathrm{C}$, indicating the presence of TW in the upper layer of the permanent thermocline.

The temperature values obtained in the winter and summer surveys were consistent with seasonal variability (lower in winter and higher in summer), and coincide with the values recorded in August 2012 and January 2013 (Figure 4). In contrast, the values of salinity present an antagonistic behavior in relation to the fluvial contribution, with higher mean salinity recorded in winter, when there is maximum fluvial contribution. However, despite the highest mean value, the lowest salinity values, approximately $35 \mathrm{psu}$, were found in winter. Considering salinity values neighboring $37 \mathrm{psu}$ in winter and 36.5 psu in summer as typical of TW, the presence of 

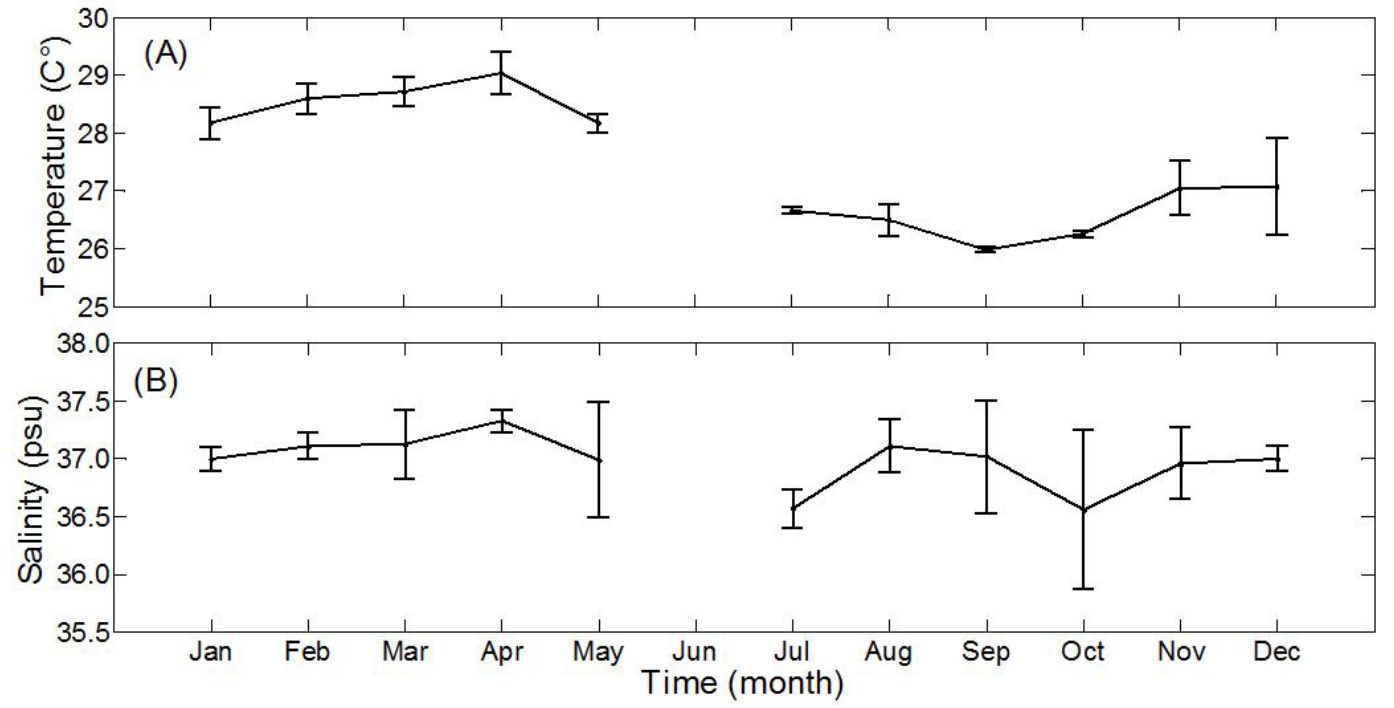

Figure 4. Seasonal variation of temperature (A) and salinity (B) in the inner shelf between March 2012 and May 2013 with the respective standard deviations.

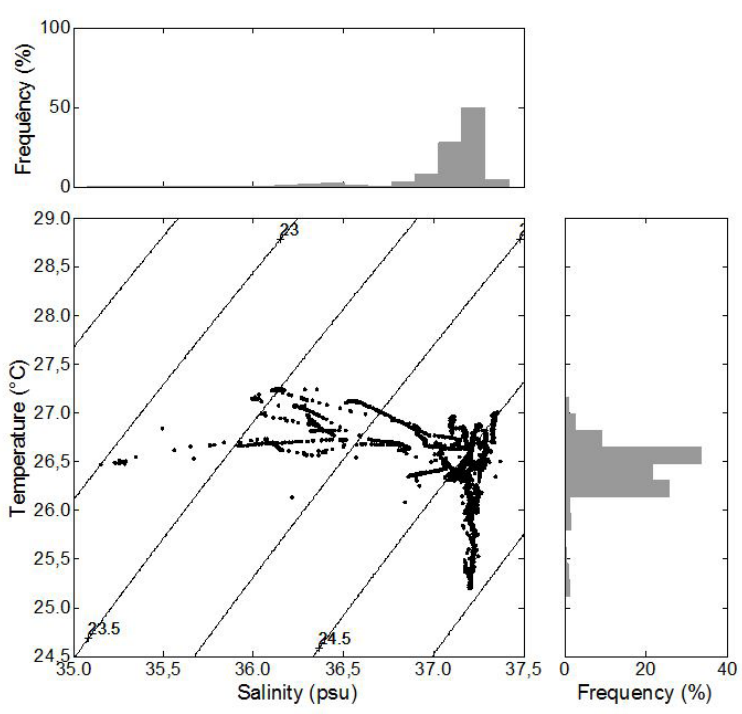

(B)
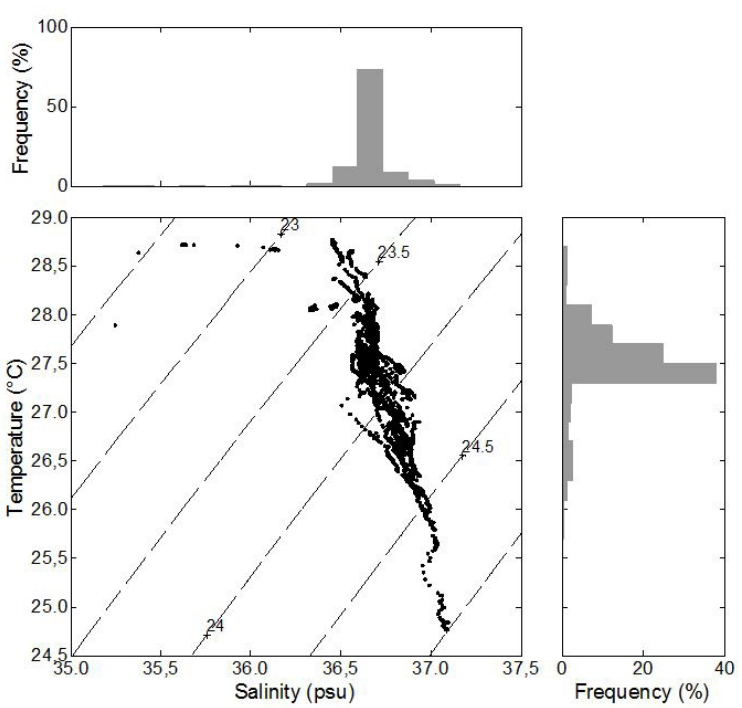

Figure 5. Temperature-Salinity Diagram for the winter (A) and summer (B) surveys. The dashed lines indicate the isopycnals in Sigma-t $(\sigma \mathrm{T})$.

$\mathrm{CW}$ was 5.0 and $2.9 \%$ in winter and summer, respectively, with contribution of 0.9 and $0.4 \%$, in the same order.

The salinity values of TW (>36.5 psu) predominant on the shelf in both winter and summer indicate great interaction between shelf and adjacent ocean. In the adjacent ocean, there is the occurrence of the NBCU, which originates from the bifurcation of the SEC when the latter flows onto the Brazilian coast at approximately $10^{\circ} \mathrm{S}$, transporting warm waters with high salinity content from the Tropical South Atlantic Ocean (SILVEIRA; MIRANDA; BROWN, 1994). The higher salinity values recorded in winter, in dissonance with the greater fluvial inflow in this period, indicate that: (1) fluvial contribution does not play a significant role in the dilution of TW to form CW; (2) the thermohaline characteristics of the shelf are mainly determined by interaction with mesoscale oceanic circulation.

\section{Spatial distribution of temperature and salinity}

Figures 6 and 7 present the cross-shelf distributions of temperature and salinity, respectively. Mean values between the depths of -0.5 and $-2 \mathrm{~m}$ were used for the surface, whereas mean values of the deepest $2 \mathrm{~m}$ were used for the bottom. The bottom distributions obviously represent different shelf depths, ranging from $5 \mathrm{~m}$ in the inner northern portion to $40-50 \mathrm{~m}$ in the outer stations.

The mean temperature values on the surface were $26.7 \pm 0.3{ }^{\circ} \mathrm{C}$ in winter and $27.9 \pm 0.3^{\circ} \mathrm{C}$ in summer (Figure 6). The mean temperature values at the bottom were $26.5 \pm 0.4{ }^{\circ} \mathrm{C}$ and $27.4 \pm 0.82^{\circ} \mathrm{C}$ in winter and summer, respectively. In winter, surface and bottom temperature distributions were relatively more 

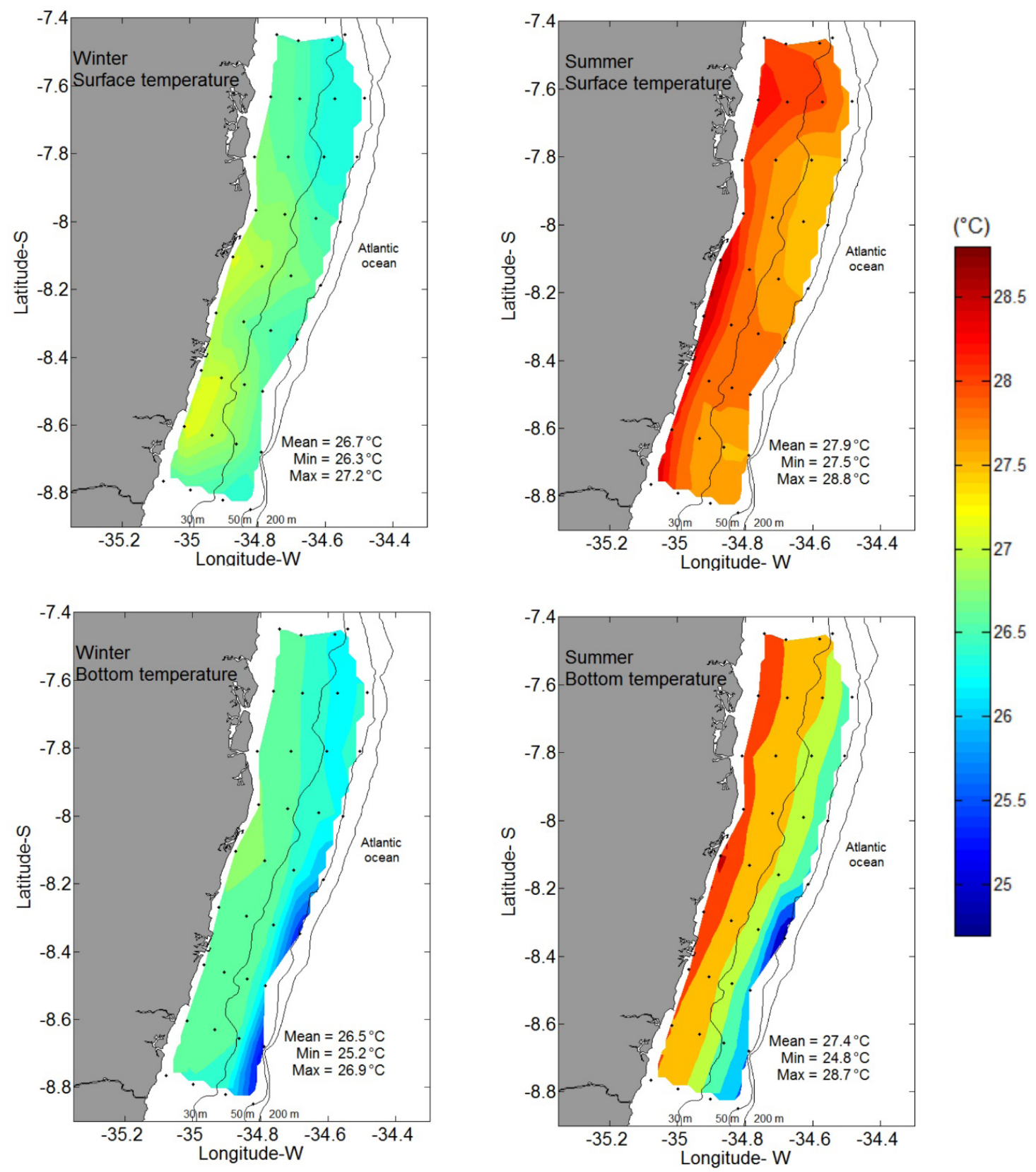

Figure 6. Horizontal distribution of water temperature $\left({ }^{\circ} \mathrm{C}\right)$ in winter (figures on the left) and summer (figures on the right), with data from the near-surface (upper figures) and near-bottom (bottom figure) of the shelf.

homogeneous compared with those in summer. Cross-shore mean thermal gradients on the surface were $0.03^{\circ} \mathrm{C} / \mathrm{km}$ in summer and $0.02^{\circ} \mathrm{C} / \mathrm{km}$ in winter, whereas mean gradients at the bottom were $0.03{ }^{\circ} \mathrm{C} / \mathrm{km}$ and $0.07^{\circ} \mathrm{C} / \mathrm{km}$ in winter and summer, respectively. In winter, the highest gradients were observed at the bottom of the southern portion near the shelf break, where lower temperature values of approximately $25^{\circ} \mathrm{C}$ were recorded. This pattern was also observed in summer, but more intense, suggesting greater intrusion of water from the upper layer of the permanent thermocline into the shelf. This has profound implications for ecology and fishery resources, as it may contribute to increased local productivity in an oligotrophic environment (FREIRE; PAULY, 2010).
In winter, the mean salinity values on the surface and at the bottom were $36.8 \pm 0.5$ and $37.1 \pm 0.28$, respectively, whereas in summer the values were $36.6 \pm 0.2$ and $36.7 \pm 0.2$ in the same order (Figure 7). In winter, salinity distribution presented positive cross-shore gradient along the whole shelf length, but more intense in the northern portion. The mean surface salinity gradients were $0.04 \mathrm{psu} / \mathrm{km}$ in winter and $0.01 \mathrm{psu} / \mathrm{km}$ in summer. The mean bottom salinity gradients were $0.02 \mathrm{psu} / \mathrm{km}$ in winter and $0.015 \mathrm{psu} / \mathrm{km}$ in summer.

A strip with lower salinity values is observed along the whole inner shelf during the winter, indicating contribution of the several small rivers to the formation of $\mathrm{CW}$ near the coast. 

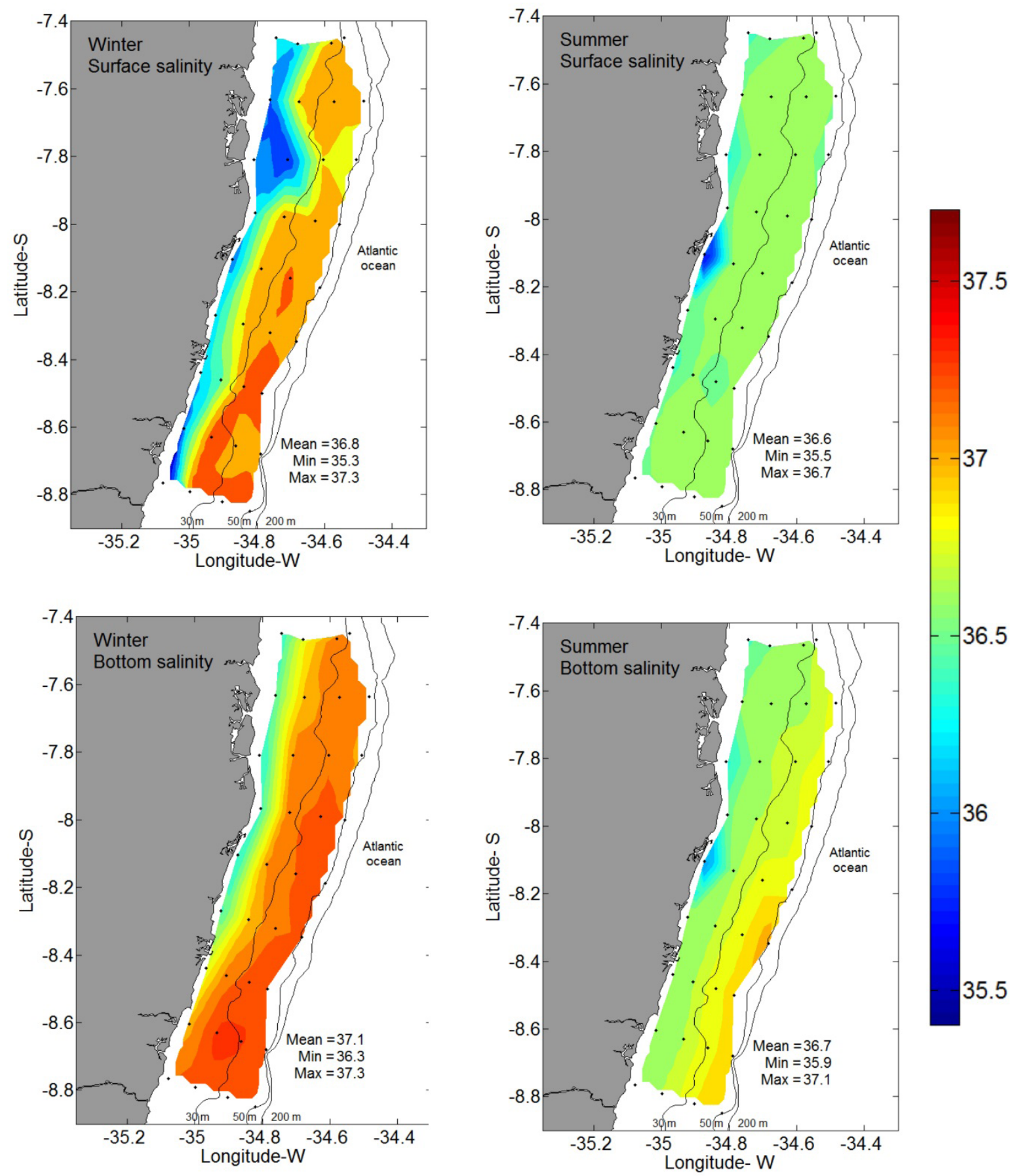

Figure 7. Cross-shore distribution of water salinity for the surveys conducted in winter (figures on the left) and summer (figures on the right), with data from the near-surface (upper figures) and near-bottom (bottom figures) of the shelf.

In summer, lower values of salinity are observed only near the mouth of the Capibaribe River (Figure 7). The discharge of local rivers is strongly determined by the regional semi-arid climate, when discharge is minimal or absent during the summer (dry season) and maximum during the winter (rainy season). The anomaly recorded in summer near the mouth of the Capibaribe River is associated with the anthropic effect of the water supply for the metropolitan region of Recife. While the other rivers present decreased flow in summer, the discharge of fresh water onto the estuary of the
Capibaribe River is maintained at approximately $10 \mathrm{~m}^{3} / \mathrm{s}$ in summer, with $80 \%$ of it occurring due to the contribution of urban water supply (SCHETTINI et al, 2016a).

Sections I, V, and VIII were selected to present the alongshore thermohaline structure of the southern, central and north transects of the study area, respectively. The sectional distribution of temperature was relatively more homogeneous in winter than in summer (Figure 8). In winter, the highest thermal gradients were observed in the south transect of the study area 

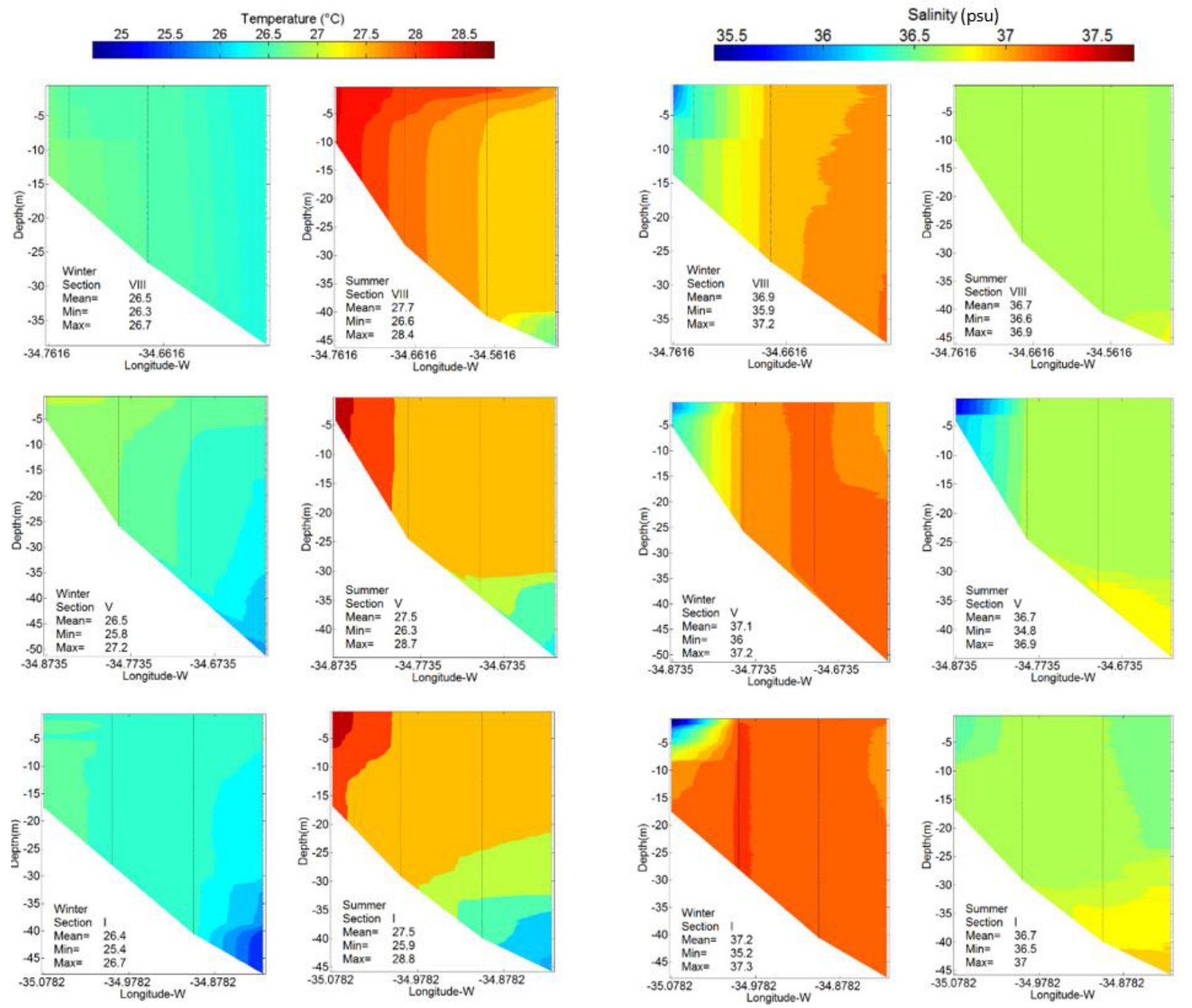

Figure 8. Distribution of temperature (figures on the left) and salinity (figures on the right) of the north (section VIII, at the top), central (section V, in the middle), and south (section I, at the bottom) transects of the study area.

(section I), with relatively cooler water $\left(\sim 25^{\circ} \mathrm{C}\right)$ occupying a quarter of the water column near the bottom. This was observed to a lesser extent in the central transect (section V), and it did not occur in the north transect (section VIII). The same pattern was observed in summer, with north-to-south intensification of the cross-shore thermal gradient.

The sectional distribution of salinity in winter showed gradient across the shelf, but with homogeneous alongshore distribution in the central and northern transects (sections V and VIII, Figure 8). In the south transect (section I), the lowest salinity values $(\sim 35.5)$ were recorded on the surface, with more intense cross- and alongshelf gradients. In summer, the distribution was relatively more homogeneous in the south and north transects (sections I and VIII), whereas smaller values were recorded near the surface and near the coast in the central transect of the study area.
The temperature distribution patterns recorded in winter and summer showed relatively small seasonal and spatial variability, and possibly reflect well the long-term behavior of the shelf. In contrast, greater variability is expected for salinity. Rainfall in the coastal region in July 2013 was 106 mm, approximately half the climatic value for July - $194 \mathrm{~mm}$ (APAC, 2016). In years with higher precipitation, greater equivalent of $\mathrm{CW}$ formation is expected, although with predominance of TW. Similar studies conducted in the south and north regions of Brazil have reported variation of more than 4 psu between the periods of high and low discharge (CARVALHO; SCHETTINI; RIBAS, 1998; SILVA; ARAÚJO; BOURLÈS, 2005), whereas in this study mean salinity in the rainy season was 0.5 psu greater than that in the dry season. 


\section{Tide, wind, and current}

This section presents the data of water level and currents obtained during the mooring of the Acoustic Doppler Current Profiler (ADCP) array, as well as data for coastal wind (Figure 9). Data obtained in winter comprise a period of 45 days, whereas data collected in summer include only 9 days (Figure 10). Nevertheless, the results allow assessment of the seasonal current regime. The water-level data provide a first record of the tides on the Brazilian Northeast Continental Shelf. Maximum neap tide height was $2.63 \mathrm{~m}$ and minimum spring tide height was $0.76 \mathrm{~m}$ (Figure 11A). Table 3 presents the harmonic tidal constituents obtained for the water level record in winter. The harmonic signal accounts for $99.7 \%$ of the water level data variance. During the summer campaign, tide height was between 1.09 and $1.94 \mathrm{~m}$ (Figure 11E).

Studies on currents in this region are not in sufficient number to allow comparison. Fishermen, sailors, and managers of offshore aquaculture sites state that the winter currents are towards the north. Previous works (HAZIN et al., 2008;
LIRA et al., 2010) corroborate the results found in the present study (Figures 11C and G).

The time series of currents are presented as oceanographic notation in Figure 11 and as polar distribution diagrams in Figure 10. Mean winter wind velocity was $4.8 \mathrm{~m} / \mathrm{s}$, with maximum value of $11 \mathrm{~m} / \mathrm{s}$ and predominant NNW direction. Mean summer wind velocity was $3.7 \mathrm{~m} / \mathrm{s}$, with maximum value of $6.7 \mathrm{~m} / \mathrm{s}$ and predominant WNW direction (Figure 9). In winter, the mean velocity of currents was $0.11 \mathrm{~m} / \mathrm{s}$, with maximum values of approximately $0.3 \mathrm{~m} / \mathrm{s}$. Predominant direction was NNE (69\%) parallel to the coastline. However, between days 250 and 265, two inversions occurred in current direction, still along-shelf but flowing in the SSW direction. In summer, the mean velocity of currents was $0.06 \mathrm{~m} / \mathrm{s}$, with a maximum value of $0.14 \mathrm{~m} / \mathrm{s}$. Direction presented a SSW mode parallel to the coast line and another mode towards the coast. Based on the mean velocities, the average time of a water mass on the shelf in winter is approximately 20 days, with displacement towards the north. In winter, the tidal currents (harmonic component) accounted for $59 \%$ and $16 \%$ of current variance in the cross- and along-shore components, respectively.
(A)

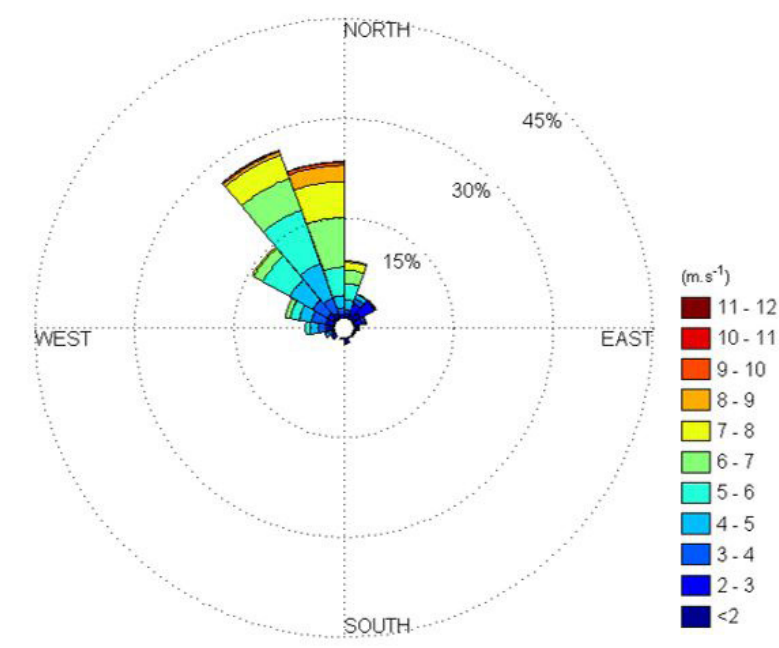

B)

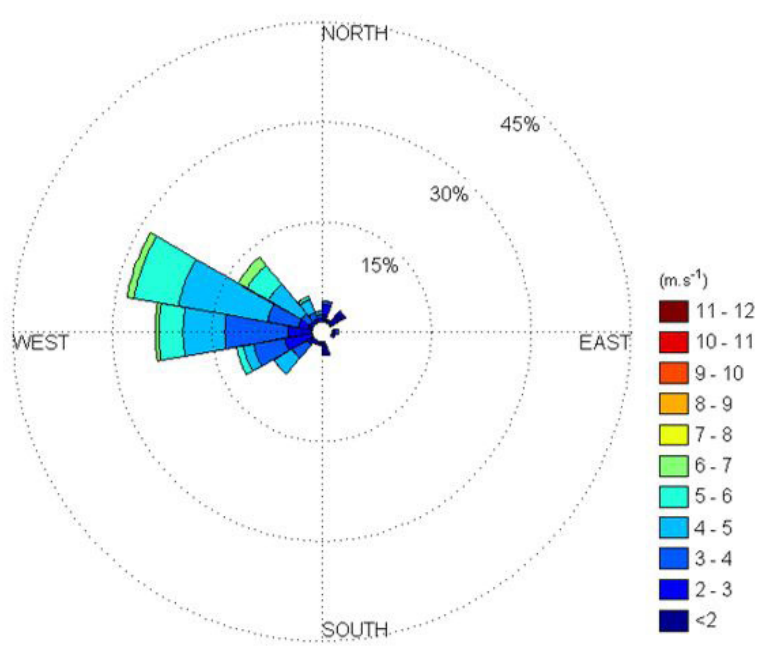

Figure 9. Direction, velocity, and intensity of the winds during the rainy (A) and dry (B) seasons.

Table 3. Harmonic tidal constituents (TC) determined for water level in August and September 2013.

\begin{tabular}{cccccc}
\hline TC & $\begin{array}{c}\text { Amplitude } \\
(\mathbf{m})\end{array}$ & $\begin{array}{c}\text { Phase } \\
\mathbf{(}^{\circ}\end{array}$ & TC & $\begin{array}{c}\text { Amplitude } \\
(\mathbf{m})\end{array}$ & $\begin{array}{c}\text { Phase } \\
\left.\mathbf{(}^{\circ}\right)\end{array}$ \\
\hline 2Q1 & 0.0038 & 56.14 & L2 & 0.0174 & 117.66 \\
Q1 & 0.0170 & 98.72 & S2 & 0.3139 & 126.58 \\
O1 & 0.0492 & 139.56 & MO3 & 0.0021 & 263.75 \\
NO1 & 0.0025 & 259.25 & M3 & 0.0063 & 105.20 \\
K1 & 0.0350 & 245.71 & SK3 & 0.0019 & 278.64 \\
J1 & 0.0038 & 347.91 & MN4 & 0.0032 & 148.81 \\
MU2 & 0.0171 & 129.83 & MS4 & 0.0079 & 190.84 \\
N2 & 0.1371 & 95.45 & S4 & 0.0042 & 313.53 \\
M2 & 0.7679 & 110.98 & & 0.0023 & 196.02 \\
\hline
\end{tabular}


(A)

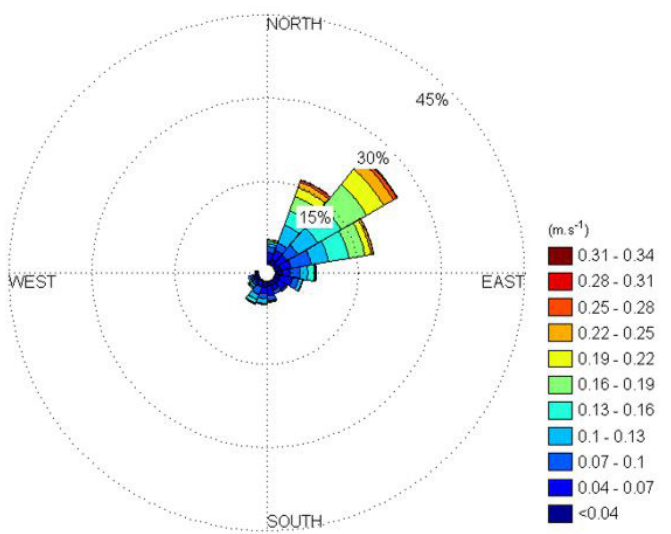

(B)

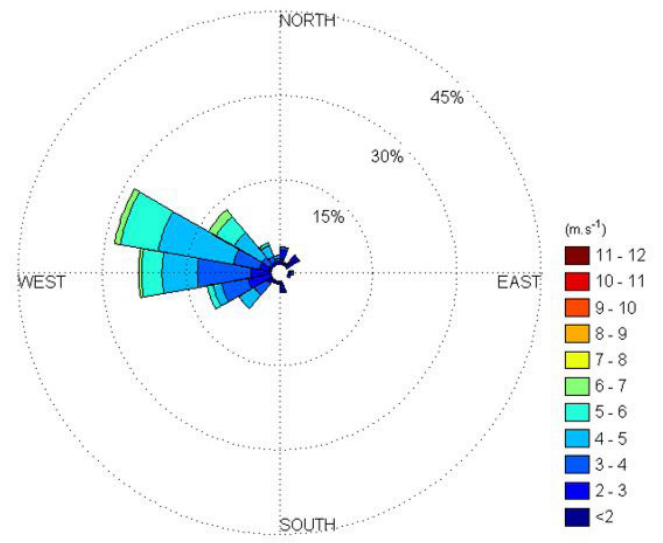

Figure 10. Direction, velocity, and intensity of the currents during the rainy (A) and dry (B) seasons.
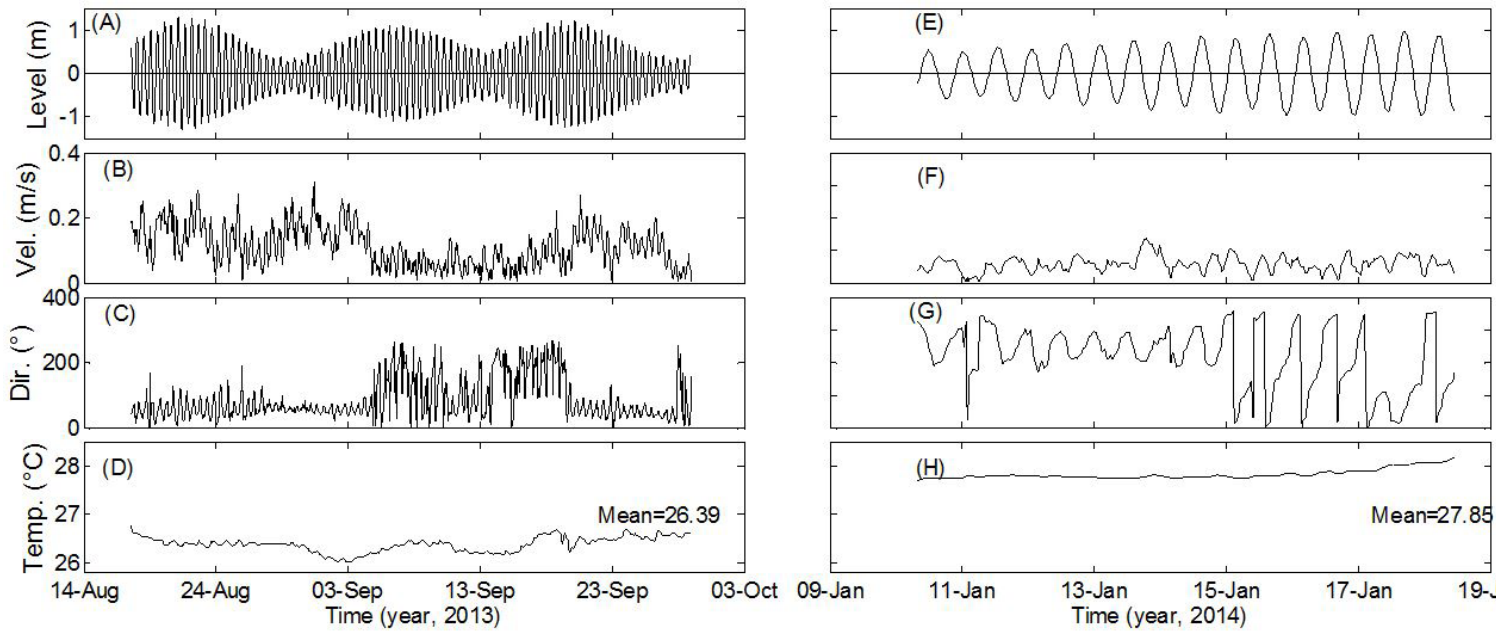

(F)
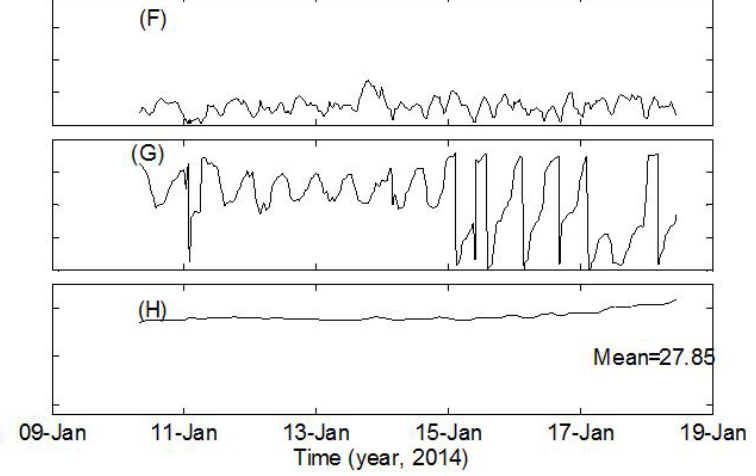

Figure 11. Time series of water level variation (A and E), current velocity (B and F), current direction (C and $G$ ), and temperature ( $\mathrm{D}$ and $\mathrm{H}$ ) in the rainy (on the left) and dry (on the right) seasons during the deployment of the ADCP mooring array.
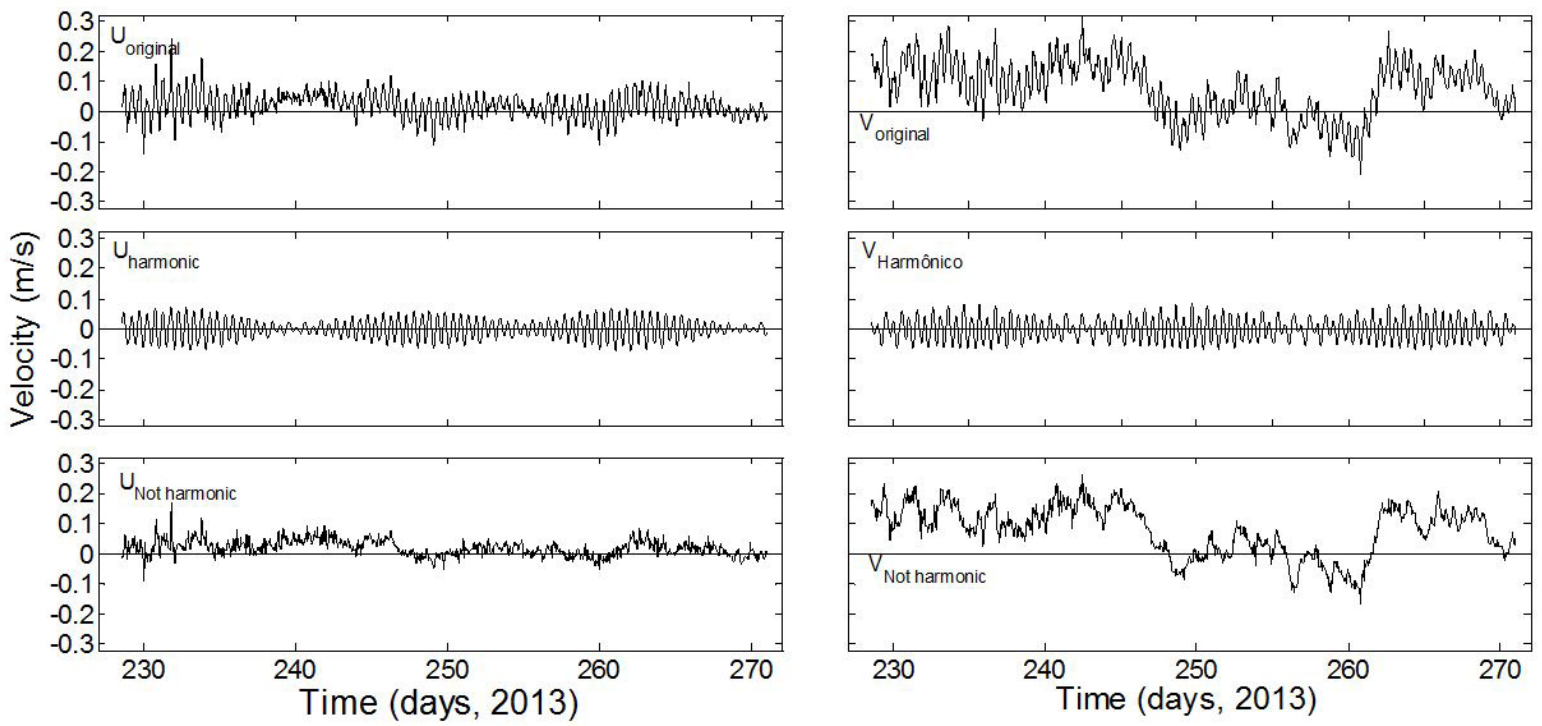

Figure 12. Time series with decomposition into the cross-shore (on the left) and alongshore (on the right) components in the original (at the top), harmonic (in the middle), and non-harmonic (at the bottom) U-V signals of the currents during the rainy season. 

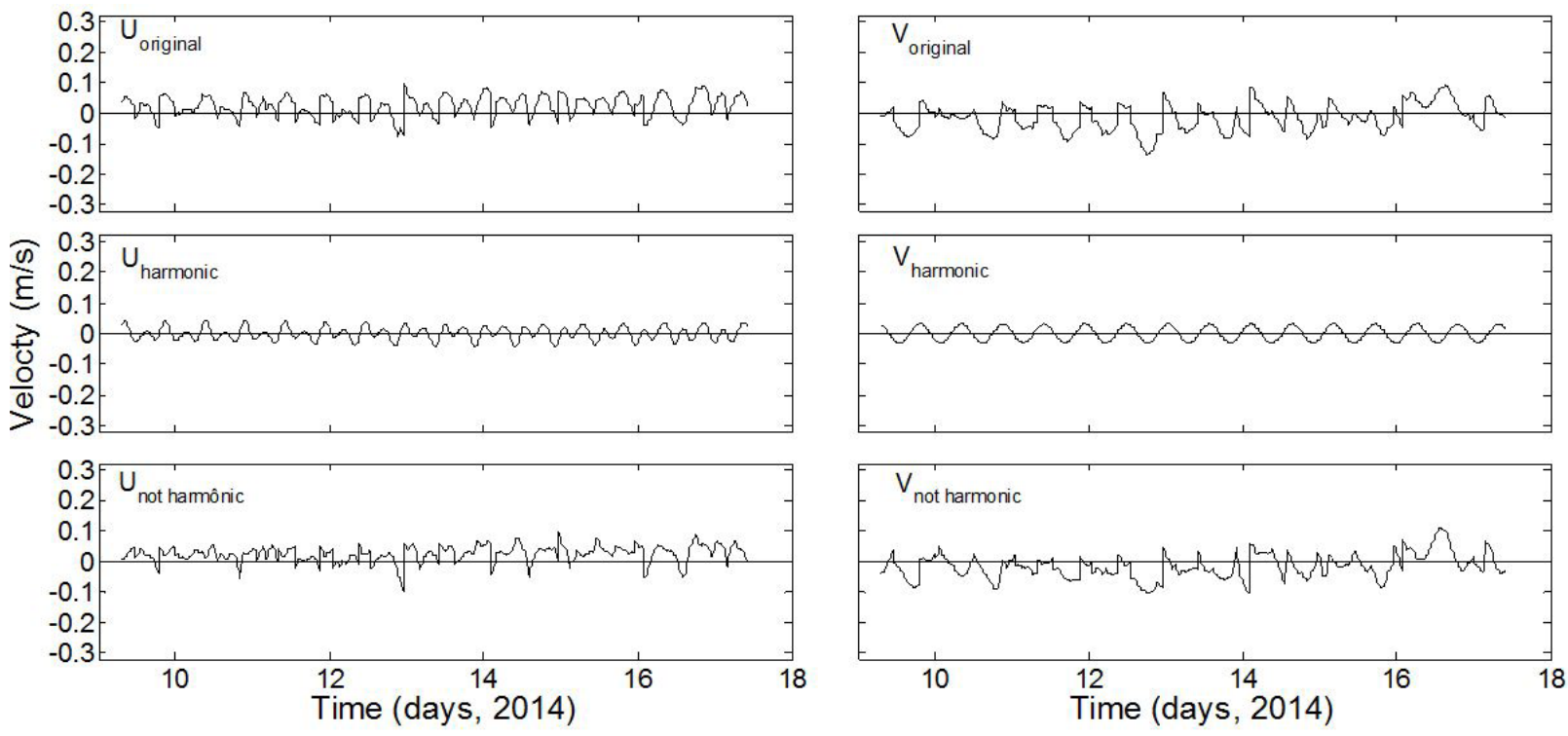

Figure 13. Time series with decomposition into the cross-shore - $U$ (on the left) and alongshore - $V$ (on the right) components in the original (at the top), harmonic (in the middle), and non-harmonic (at the bottom) U-V signals of the currents during the dry season.

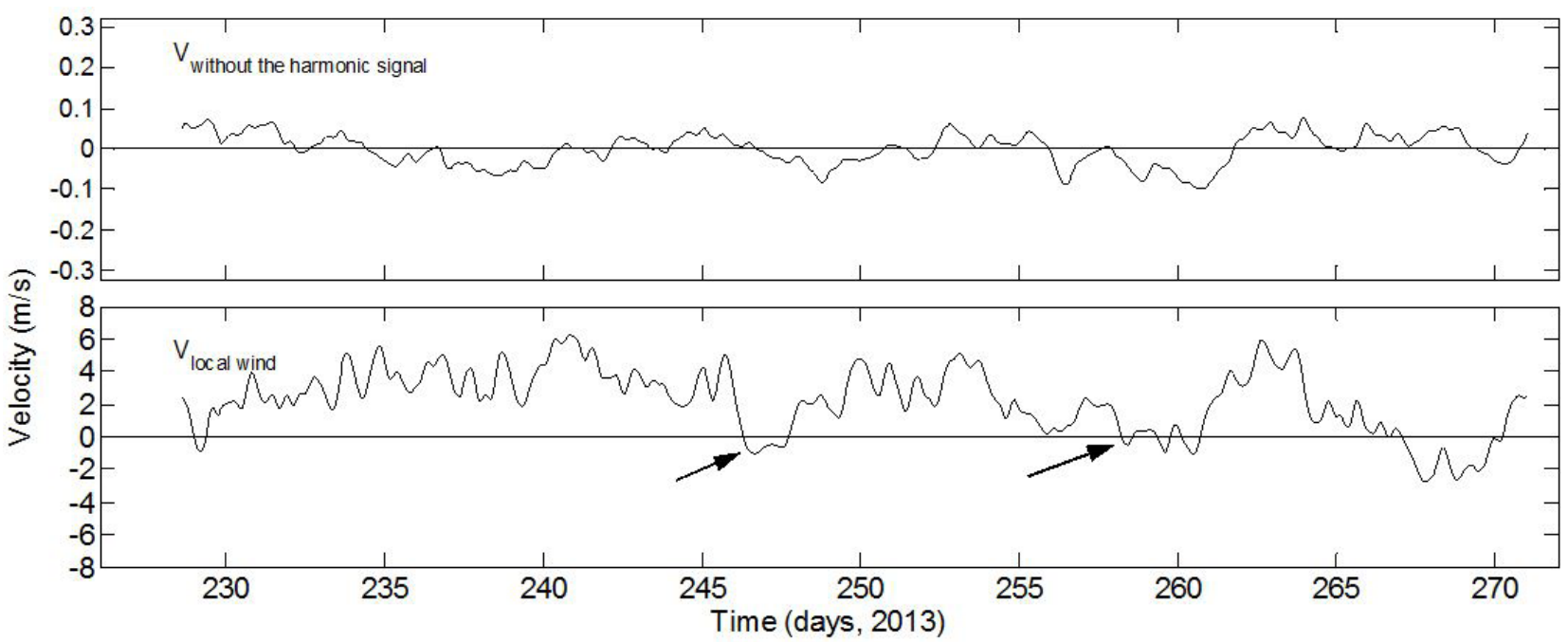

Figure 14. Seasonal series of the non-harmonic, alongshore component with the local wind, alongshore component.

In summer, the energy associated with tide was $76 \%$ and $43 \%$ for the cross- and along-shore components, respectively

Figures 12 and 13 show the time series for currents decomposed into their respective cross- and along-shore components. The alongshore component of the currents concentrates most of the energy during the winter. In winter, the cross-shore component of the currents is offshore when the alongshore component is northwards.

Although the recording of currents in summer comprises only 9 days, the result is expected to represent the summer conditions fairly well, when the prevailing wind is milder and almost orthogonal to the coast line. As for winter, it is worth noting that, in the period between days 250 and 265 (Figure 14), the currents were much more sluggish compared with those recorded on the other assessment days, being an unexpected result to some extent. Had the records been obtained only during this period, the diagnosis of current pattern would have been quite distorted from reality, which emphasizes the need for long recording periods to produce an adequate evaluation of currents in the shelf.

The ratio between local wind and remote wind recorded by the PIRATA float (NOAA, 2016); $8^{\circ} \mathrm{S}, 30^{\circ} \mathrm{W} ; 540 \mathrm{~km}$ off the coast) was examined using data collected from currents during the winter. A simple correlation with phase delay and a spectral analysis were applied and no relation was identified, although the relationships can be detailed using wavelet analysis. Figure 15 shows the analysis of wavelets and spectral energy between winds and currents along the coast. Warm colors indicate higher energy in the specific frequency band (y-axis, in hours) and in the specific time (x-axis). The thick solid line expresses the significance level of $5 \%$ and the thin solid line indicates the cone of influence.

Wind presents energy concentration in all the records within the 9-12.5-hour band, in which current spectrum does 

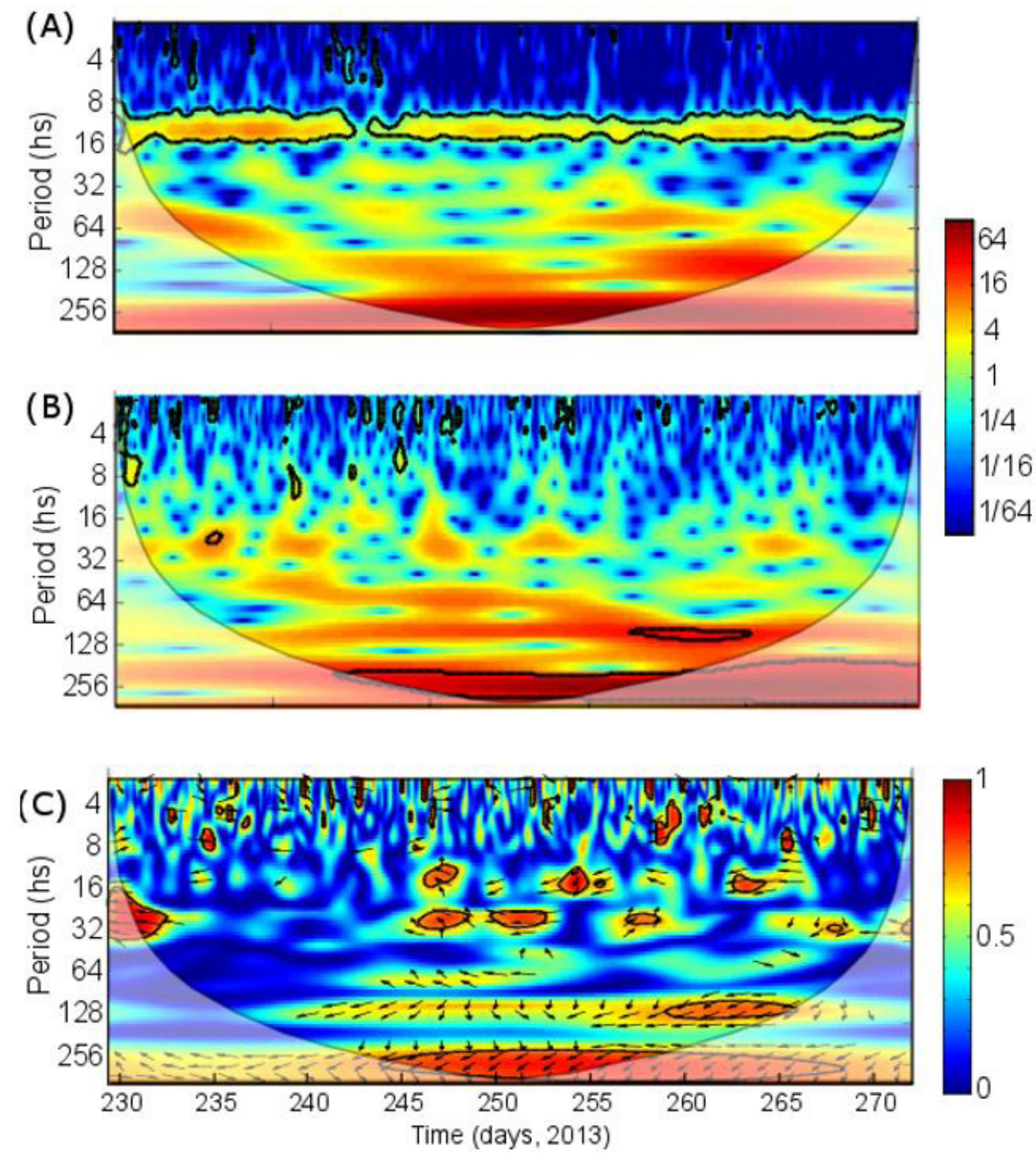

Figure 15. Wavelets and energy spectrum by time in Julian days in winter of the alongshore component between wind (A) and current (B), and analysis of wavelets with phase spectrum between the alongshore components between wind and current (C).

not occur because this energy band is associated with the semidiurnal constituents (M2 and S2) that had been removed in the harmonic analysis. A consistent characteristic in the spectra of wind and current is the energy concentration in the bands from 3.5 to 6 and 8.5 to 13 days, in the data periods of days 245 to 260 and of 259 to 265 , respectively, coinciding with the periods of wind relaxation and inversions of current direction (Figure 14). This pattern is also present in phase coherence in the energy spectrum (Figure 15C).

Covariance between the variables is shown in red (high covariance) and blue (low covariance) colors. The phases are represented by arrows: inside the phase, arrow pointing to the right (with little or no phase delay in the correlation); outside the phase, arrow pointing to the left $\left(180^{\circ}\right.$, inverse relationship with little or no delay); arrow pointing up indicates that the first variable is in function of the second one; arrow pointing down indicates that the second variable is in function of the first one. The results showed that there is significant correlation between current and local wind in all energy bands, indicating that the current (north) was induced by the local wind (coming from the south).

The periods of wind and current energy concentration raging from 6 to 13 days coincide with the periodicity found for cold front air systems on the southeastern coast of Brazil (STECH; LORENZZETTI, 1992). Although no significant change is observed in wind direction, apparently the currents on the Brazilian Northeast Continental Shelf are somehow affected by frontal instabilities of mid-latitudes.

The occurrence of a frequent component towards the coast in summer is an unexpected pattern, considering that the currents tend to align mainly on the alongshore axis. This pattern suggests the presence of a circulation cell across the shelf which may have important implications in the processes of transport and interaction between coast and ocean (BRINK, 2016), with important implication in the same processes between the shelf and the adjacent ocean. 


\section{CONCLUSIONS}

The highest values of temperature and salinity in the Pernanbuco Continental Shelf (PCS) were observed in the month of April.

The thermohaline characteristics in the eastern portion of the northeastern region of Brazil are controlled by the presence of Tropical Water (TW), with values of temperature $>26{ }^{\circ} \mathrm{C}$ and salinity $>36.5$ psu. Mean annual temperature and salinity values are approximately $3{ }^{\circ} \mathrm{C}$ to 0.5 psu, respectively. TW accounted for more than $95 \%$ of the water mass of the shelf. The presence of Coastal Water (CW) formed by the discharge from small rivers was slightly higher in winter, but it was restricted to the inner shelf on both occasions. The across- and along-shelf spatial distribution of temperature and salinity were relatively monotonous, although the highest thermal gradient was observed near the coast in summer and the haline gradient was observed further from the coast in winter. The highest alongshore thermal gradient was recorded in the southern portion of the shelf near the slope break, indicating the presence of water coming from the upper layer of the permanent thermocline. Results show that the PCS is controlled by oceanic water masses coming from the bifurcation of the South Equatorial Current (SEC).

In winter, the currents are more intense and predominantly towards the north. After short periods of wind relaxation, the current velocity decreases and its direction reverses without justification. Analysis of the data showed no justifiable association between the wind and the currents. The tidal currents along the continental shelf (alongshore) accounted for 16\% of current intensity. The combination of a short shelf with TW predominance reinforces the hypothesis that the dynamics in the continental shelf under study is associated with mesoscale processes. In summer, the currents were sluggish and with no predominant direction - a classic behavior of tidal currents. The tides represented more than $75 \%$ of the currents of the alongshore component. The winds at this time reached the coastline at an almost perpendicular angle and the currents did not present a predominant direction; a fact that has drawn attention was that, at some moments, currents towards the coast were observed.

\section{ACKNOWLEDGEMENTS}

The present study was financially supported by "Conselho Nacional de Desenvolvimento Científico e Tecnológico” (CNPq) (proc. no. 485964/2011-2), INCT-AmbTropic (proc. no. 565054/2010-4), and "Fundação de Amparo à Ciência e Tecnologia do Estado de Pernambuco" (FACEPE) (proc. no. 0079-1.08/11). ECD is grateful to "Comissão de Aperfeiçoamento de Pessoal do Nível Superior" (CAPES) for the financial support received. CAFS holds a grant from CNPq: Research Grant no. 308665/2013-9. ECT holds a grant from CNPq/Facepe: Post-Doc Grant no. 0060-1.08/11.

\section{REFERENCES}

ANDREOLI, R. V.; KAYANO, M. T. A importância relativa do Atlântico Tropical Sul e Pacífico Leste na variabilidade da precipitação do Nordeste do Brasil. Revista Brasileira de Meteorologia., v. 22, n. 1, p. 63-74, 2007. http://dx.doi.org/10.1590/S010277862007000100007.

APAC - AGÊNCIA PERNAMBUCANA DE ÁGUA E CLIMA. Meteorologia. Recife, 2016. Available from: <http://www.apac. pe.gov.br/meteorologia/>. Access on: 21 oct. 2016.

BRASIL. Ministério de Meio Ambiente. Atlantico nordeste oriental: caderno da região hidrográfica. Brasília: Ministério do Meio Ambiente, 2006. 104 p.

BRINK, K. H. Cross-shelf exchange. Annual Review of Marine Science, v. 8, n. 1, p. 59-78, 2016. PMid:26747520. http://dx.doi. org/10.1146/annurev-marine-010814-015717.

CARVALHO, J. L. B.; SCHETTINI, C. A. F.; RIBAS, T. M. Estrutura termohalina do litoral centro-norte catarinense. Notas Técnicas da Facimar, v. 2, p. 181-197, 1998.

CASTRO, B. M. F. Estado atual do conhecimento dos processos físicos das águas da Plataforma Continental Sudeste do Brasil. In: SIMPÓSIO DE ECOSSISTEMAS DA COSTA SUL E SUDESTE BRASILEIRA, 2., 1990, Águas de Lindóia. Anais... São Paulo: ACIESP. v. 1, p. 1-19, 1990.

DENGLER, M.; SCHOTT, F. A.; EDEN, C.; BRANDT, P.; FISCHER, J.; ZANTOPP, R. J. Break-up of the Atlantic deep western boundary current into eddies at 8 degrees S. Nature, v. 432, n. 7020, p. 1018-1020, 2004. PMid:15616560. http://dx.doi. org/10.1038/nature03134.

DIAS, F. J. S.; CASTRO, B. M.; LACERDA, L. D. Continental shelf water masses off the Jaguaribe River $\left(4^{\circ} \mathrm{S}\right)$, northeastern Brazil. Continental Shelf Research, v. 66, p. 123-135, 2013. http:// dx.doi.org/10.1016/j.csr.2013.06.005.

EMÍLSSON, I. The shelf and coastal waters off southern Brazil. Boletim do Instituto Oceanografico., v. 11, n. 2, p. 101-112, 1961. http:/ / dx.doi.org/10.1590/S0373-55241961000100004.

FEMAR - FUNDAÇÃO DE ESTUDOS DO MAR. Catálogo de estações maregráficas brasileiras. Rio de Janeiro, 2000. Available from: <https://www.fundacaofemar.org.br/biblioteca/emb/prefacio. html>. Access on: 15 nov. 2016.

FREIRE, K. M. F.; PAULY, D. Fishing down Brazilian marine food webs, with emphasis on the east Brazil large marine ecosystem. Fisheries Research, v. 105, n. 1, p. 57-62, 2010. http://dx.doi. org/10.1016/j.fishres.2010.02.008.

FROTA, F. F.; TRUCCOLO, E. C.; SCHETTINI, C. A. F. Tidal and sub-tidal sea level variability at the northern shelf of Brazilian Northeast Region. Anais da Academia Brasileira de Ciências, v. 88, n. 3, p. 1371-1386, 2016. PMid:27580361. http://dx.doi. org/10.1590/0001-3765201620150162.

GEYER, W. R.; BEARDSLEY, R. C.; LENTZ, S. J.; CANDELA, J.; LIMEBURNER, R.; JOHNS, W. E.; CASTRO, B. M.; SOARES, 
I. D. Physical oceanography of the Amazon shelf. Continental Shelf Research, v. 16, n. 5-6, p. 575-616, 1996. http://dx.doi. org/10.1016/0278-4343(95)00051-8.

GRINSTED, A.; MOORE, J. C.; JEVREJEVA, S. Application of the cross wavelet transform and wavelet coherence to geophysical time series. Nonlinear Processes in Geophysics, v. 11, n. 5/6, p. 561-566, 2004. http://dx.doi.org/10.5194/npg-11-561-2004.

HAZIN, F. V. H.; WOR, C.; LINS, J. L. O.; HAMILTON, S.; TRAVASSOS, P.; GEBER, F. Resultados obtidos por meio do fundeio de um correntógrafo na plataforma continental do estado do Rio grande do norte, Brasil. Arquivo de Ciência do Mar, v. 41, n. 1, p. 30-35, 2008.

HILLE, E.; SCHETTINI, C. A. F.; RIBEIRO, M. R. Estrutura termohalina no litoral de Santa Catarina nos anos de 2005 e 2006. In: BRAGA, E. S. (Org.). Oceanografia e mudanças globais. São Paulo: EDUSP, 2008. p. 371-382.

KNOPPERS, B.; EKAU, W.; FIGUEIREDO, A. G. The coast and shelf of east and northeast Brazil and material transport. Geo-Marine Letters, v. 19, n. 3, p. 171-178, 1999. http://dx.doi. org/10.1007/s003670050106.

LIRA, L.; WOR, C.; HAZIN, F. H. V.; BRAGA JUNIOR, H. A. C.; SANTOS, J. C. P. Estudo de correntes marinhas por meio de lançamento de cartões de deriva no litoral do estado de Pernambuco. Arquivos de Ciências do Mar, v. 43, n. 1, p. 30-37, 2010.

MACIEL, D. C.; SOUZA, J. R. B.; TANIGUCHI, S.; BICEGO, M. C.; SCHET'TINI, C. A. F.; ZANARDI, E. Hydrocarbons in sediments along a tropical estuary-shelf transition area: sources and spatial distribution. Marine Pollution Bulletim, v. 113, n. 1-2, 2016. http:/ /dx.doi.org/10.1016/j.marpolbul.2016.08.048.

MANSO, V. A. V.; CORREA, I.; GUERRA, N. Morfologia e sedimentologia da Plataforma Continental Interna entre as Prais Porto de Galinhas e Campos-Litoral Sul de Pernambuco, Brasil. Pesquisas Em Geociências., v. 30, n. 2, p. 17-25, 2003.

MARIN, F. O. A sub-corrente norte do Brasil ao largo da costa do Nordeste. 2009. 115 f. Dissertação (Mestrado em Ciências) - Universidade de São Paulo, São Paulo, 2009.

MIRANDA, L. B. Forma da correlação T-S de massas de água das regiões costeira e oceânica entre o Cabo de São Tomé (RJ) e a Ilha de São Sebastião (SP), Brasil. Boletim do Instituto Oceanográfico, v. 33, n. 2, p. 105-119, 1985. http://dx.doi.org/10.1590/S037355241985000200002 .

MOLLER JUNIOR, O. O.; PIOLA, A. R.; FREITAS, A. C.; CAMPOS, E. J. D. The effects of river discharge and seasonal winds on the shelf off southeastern South America. Continental Shelf Research, v. 28, n. 13, p. 1607-1624, 2008. http://dx.doi. org/10.1016/j.csr.2008.03.012.

NOAA - NATIONAL OCEANIC AND ATMOSPHERIC ADMINISTRATION. Atlantic Ocean-PIRATA. Seattle, 2016.
Available from: <http://www.pmel.noaa.gov/pirata/>. Access on: 8 aug. 2016.

ORTEGA, L.; MARTÍNEZ, A. Multiannual and seasonal variability of water masses and fronts over the uruguayan shelf. Journal of Coastal Research, v. 23, n. 3, p. 618-629, 2007. http:// dx.doi.org/10.2112/04-0221.1.

PAWLOWICZ, R.; BEARDSLEY, B.; LENTZ, S. Classical tidal harmonic analysis including error estimates in MATLAB using T_TIDE. Computers \& Geosciences, v. 28, n. 8, p. 929-937, 2002. http://dx.doi.org/10.1016/S0098-3004(02)00013-4.

PEREIRA, A. F.; CASTRO, B. M.; CALADO, L.; SILVEIRA, I. C. A. Numerical simulation of M2 internal tides in the South Brazil Bight and their interaction with the Brazil Current. Journal of Geophysical Research: Oceans, v. 112, n. 4, 2007.

PEREIRA, P. S.; NOGUEIRA NETO, A. V. Caracterização do clima de ondas ao largo da costa de Pernambuco a partir de dados da PNBOIA Recife. In: SIMPÓSIO SOBRE ONDAS, MARÉS, ENGENHARIA OCEANICA E OCEANOGRAFIA POR SATÉLITE, 11., 2010, Arraial do Cabo, Anais... Arraial do Cabo: Instituto de Estudos do Mar Almirante Paulo Moreira, 2010. Available from: <https://media.wix.com/ugd/f9878c_5ec ea524ef81483c8820998f479a8894.pdf>. Access on: 10 oct. 2016.

PEREIRA, T. Influência do relevo na precipitação das regiões hidrográficas do litoral norte de Alagoas. GEOUSP: Espaço e Tempo, v. 33, p. 239-253, 2013.

PUGH, D. T. Tides, surges and mean sea-level. New York: John Wiley \& Sons, 1987. $472 \mathrm{p}$.

RAMOS, A. M.; SANTOS, L. A. R.; FORTES, L. T. G. Normas Climatológicas do Brasil 1961-1990. Brasília: Instituto Nacional de Meteorologia, 2009. 465 p.

SCHETTINI, C. A. F.; MIRANDA, J. B.; VALLE-LEVINSON, A.; TRUCCOLO, E. C.; DOMINGUES, E. C. The circulation of the lower Capibaribe estuary (Brazil) and its implications in the transport of scalars. Brazilian Journal of Oceanography, v. 64, n. 3, p. 263-276, 2016a. http://dx.doi.org/10.1590/S167987592016119106403 .

SCHETTINI, C. A. F.; PAIVA, B. P.; BATISTA, A. L.; OLIVEIRA FILHO, J. C.; TRUCCOLO, E. C. Observation of an estuarine turbidity maximum in the highly impacted Capibaribe Estuary, Brasil. Brazilian Journal of Oceanography, v. 64, n. 2, p. 185-190, 2016b. http://dx.doi.org/10.1590/S1679-87592016115006402.

SCHMIEGELOW, J. M. M. O planeta ąul: uma introdução às ciências marinhas. Rio de Janeiro: Editora Interferência, 2004. 379 p.

SCHOT'T, F. A.; DENGLER, M.; ZANTOPP, R.; STRAMMA, L.; FISCHER, J.; BRANDT, P. The Shallow and Deep Western Boundary Circulation of the South Atlantic at $5^{\circ}-11^{\circ} \mathrm{S}$. Journal of Physical Oceanography, v. 35, n. 11, p. 2031-2053, 2005. http:// dx.doi.org/10.1175/JPO2813.1. 
SILVA, A. C.; ARAÚJO, M.; BOURLÈS, B. Variação sazonal da estrutura de massas de água na plataforma continental do amazonas e area oceánica adjacente. Revista Brasileira de Geofisica, v. 23, n. 2, p. 145-157, 2005. http://dx.doi.org/10.1590/S0102261X2005000200004.

SILVA, M.; ARAUJO, M.; SERVAIN, J.; PENVEN, P.; LENTINI, C. A. D. High-resolution regional ocean dynamics simulation in the southwestern tropical Atlantic. Ocean Modelling, v. 30, n. 4, p. 256-269, 2009. http://dx.doi.org/10.1016/j.ocemod.2009.07.002.

SILVEIRA, I. C. A.; MIRANDA, L. B.; BROWN, W. S. On the origins of the North Brazil Current. Journal of Geophysical Research, v. 99, n. C11, p. 22501-22512, 1994. http://dx.doi. org/10.1029/94JC01776.

STECH, J. L.; LORENZZETTI, A. The response of the south Brazil bight to the passage of wintertime cold fronts. Journal of Geophysical Research, v. 97, n. C6, p. 9507-9520, 1992. http://dx.doi. org/10.1029/92JC00486.

STRAMMA, L.; PETERSON, R. G. The South Atlantic current. Journal of Physical Oceanography, v. 20, n. 6, p. 846-859, 1990. http:/ / dx.doi.org/10.1175/1520-0485(1990)020<0846:TSAC>2.0.CO;2.

TORRENCE, C.; COMPO, G. P. A pratical guide to wavelet analysis. Bulletin of the American Meteorological Society, v. 79, n. 1, p. 61-78, 1998.
UNESCO - UNITED NATIONS EDUCATIONAL, SCIENTIFIC AND CULTURAL ORGANIZATION. Background papers and supporting data on the Practical Salinity Scale 1978. Paris, 1981.

VITAL, H.; GOMES, M. P.; TABOSA, W. F.; FRAZÃO, E. P.; SANTOS, C. L. A.; PLÁCIDO JÚNIOR, J. S. Characterization of the Brazilian continental shelf adjacent to Rio Grande do Norte State, NE Brazil. Brazilian Journal of Oceanography, v. 58, n. 1, p. 4354, 2010. http://dx.doi.org/10.1590/S1679-87592010000500005.

WRIGHT, L. D. Morphodynamics of inner continental shelves. Virginia: Marine Science, 1995.

\section{Authors contributions}

Ernesto de Carvalho Domingues: Made whole the data collect, all the analysis and wrote the paper.)

Carlos Augusto França Schettini: Oriented the first author and aided in the whole steps of the construction process of the study.

Eliane Cristina Truccolo: She contributed in the meteorological topics, in the the Wavelet analysis as well as the paper's review.

José Cavalcante de Oliveira Filho: He participated some of data collecting campaigns, he aided in the processing of data on specialized software and contributed with the paper's review. 